\title{
The Influence of Different Age Buildings in People Lifestyle - Case of Kruja, Albania
}

\author{
Klodjan Xhexhi ${ }^{1, *}$, Paul Louis Meunier ${ }^{2}$ \\ ${ }^{1}$ Faculty of Architecture and Urban Design, Polytechnic University of Tirana, Albania \\ ${ }^{2}$ École Spéciale des Travaux Publics (ESTP), France
}

Copyright $(2019$ by authors, all rights reserved. Authors agree that this article remains permanently open access under the terms of the Creative Commons Attribution License 4.0 International License

\begin{abstract}
The aim of this paper is to analyse the people behaviour in different age buildings and different buildings typology. In the city of Kruja (Albania) exists mostly three types of buildings: the historical ones (medieval), the socialist ones (which belongs to the former communist regime) and the modern buildings. Each of them has different social and physics characteristics, different energy exchange and different building materials. The influence of all these characteristics in the exchange of energy and how they reflect in changing the lifestyle of Kruja's people is going to be analysed. A questionnaire will be undertaken to understand the way of life of Kruja's people and to draw conclusions. A comparative analysis between all these typology of buildings will be undertaken in order to understand better the behaviour of Kruja's people lifestyle living in these buildings. Although the conditions are not good, people tend to get a high level of place attachment and loyalty to the building they are living. The biggest energy consumers are the historical buildings and socialist ones; although the bills of the electricity are smaller than the third category they consume alternative energies and have major problems with thermal bridges. The most unfriendly categories are the socialist buildings. They prefer not to socialize much in comparison with the other two categories.
\end{abstract}

Keywords People Lifestyle, Different Age Buildings, Occupancy Behaviour, Energy Exchange

\section{Introduction}

\subsection{Geographical Position}

The city of Kruja is located in the North-central Albania right between Mount Krujë and the Ishëm River, the city is only $20 \mathrm{~km}$ from the capital of Albania, Tirana and $37 \mathrm{~km}$ from its district Durres. Population of the city is 17000 inhabitants and the Area of the city is $372 \mathrm{~km}$.
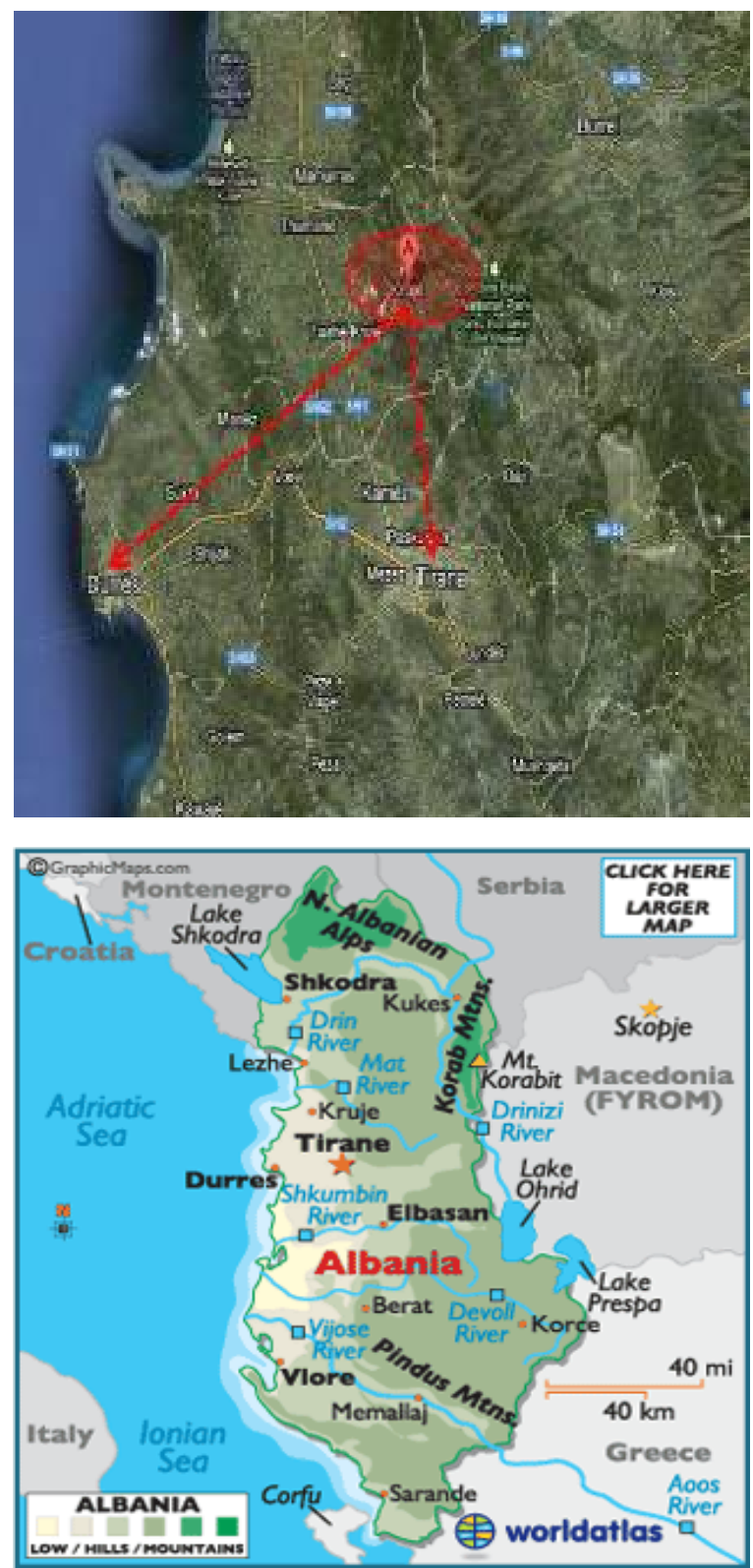

Figure 1. Geographical position of Kruja; (source: Google earth) 


\subsection{Climate Analyses}

The city of Kruja belongs to a transitory climate, in the middle of the Continental climate and Mediterranean climate, with the biggest impact of the Continental one. The average annual temperature in the city of Kruja is 20-26 degree Celsius. In the winter time the temperature can fall down till to -5 to -6 Degree Celsius. Meanwhile in the summer time the temperature varied from 30 to 32 degree Celsius and in particular day till to 34-35 degree Celsius. In the following tables are giving some of the main dates of some of the biggest city in Albania [1].

Table 1. Albanian geographical positioned of some of the main cities; Science Academy

\begin{tabular}{|c|c|c|c|c|}
\hline $\mathrm{Nr}$ & City & $\begin{array}{l}\text { Height above sea level } \\
(\mathrm{m})\end{array}$ & $\begin{array}{l}\text { Geographical latitude } \\
\text { (degree, min) }\end{array}$ & $\begin{array}{c}\text { Temperature } \\
\text { (min) }\end{array}$ \\
\hline 1 & Ballsh & 190 & $40 \quad 36$ & -1.0 \\
\hline 2 & B. Curri & 360 & $42 \quad 21$ & -9.0 \\
\hline 3 & Berat & 226 & $40 \quad 43$ & -1.0 \\
\hline 4 & Bilisht & 890 & $40 \quad 37$ & -11.0 \\
\hline 5 & Burrel & 309 & 4136 & -6.0 \\
\hline 6 & Cerrik & 80 & $41 \quad 01$ & -1.0 \\
\hline 7 & Corovode & 410 & $40 \quad 30$ & -2.0 \\
\hline 8 & Durres & 5 & $41 \quad 18$ & 1.0 \\
\hline 9 & Elbasan & 100 & 4105 & -1.0 \\
\hline 10 & Erseke & 1030 & $40 \quad 20$ & -9.0 \\
\hline 11 & Fier & 12 & $40 \quad 44$ & 0.0 \\
\hline 12 & Gramsh & 200 & $40 \quad 52$ & -2.0 \\
\hline 13 & Gjirokaster & 193 & $40 \quad 05$ & -3.0 \\
\hline 14 & Himare & 30 & $40 \quad 06$ & 1.0 \\
\hline 15 & Kavaje & 16 & $41 \quad 11$ & 0.0 \\
\hline 16 & Konispol & 400 & $39 \quad 39$ & 1.0 \\
\hline 17 & Koplik & 70 & $42 \quad 13$ & -3.0 \\
\hline 18 & Korce & 899 & $40 \quad 36$ & -10.0 \\
\hline 19 & Kruje & 560 & 4130 & -3.0 \\
\hline 20 & Krume & 434 & $42 \quad 11$ & -12.0 \\
\hline 21 & Kucove & 32 & $40 \quad 48$ & -1.0 \\
\hline 22 & Kukes & 350 & $42 \quad 02$ & -12.0 \\
\hline 23 & Lac & 25 & $41 \quad 38$ & 0.0 \\
\hline 24 & Lezhe & 20 & $41 \quad 47$ & -1.0 \\
\hline 25 & Librazhd & 250 & $41 \quad 11$ & -4.0 \\
\hline 26 & Lushnje & 19 & $40 \quad 57$ & 0.0 \\
\hline 27 & Peshkopi & 657 & $41 \quad 41$ & -11.0 \\
\hline 28 & Permet & 240 & $40 \quad 14$ & -2.0 \\
\hline 29 & Pogradec & 720 & $40 \quad 54$ & -6.0 \\
\hline 30 & Puke & 810 & $42 \quad 02$ & -11.0 \\
\hline 31 & Reshen & 100 & $41 \quad 04$ & -4.0 \\
\hline 32 & Sarande & 23 & $39 \quad 52$ & 3 \\
\hline 33 & Shkoder & 30 & $42 \quad 05$ & -3.0 \\
\hline 34 & Tepelene & 220 & $40 \quad 18$ & -1.0 \\
\hline 35 & Tirane & 110 & $41 \quad 20$ & -1.0 \\
\hline 18 & Vlore & 4 & $40 \quad 27$ & 1.0 \\
\hline
\end{tabular}

Institution of Hidro-meteorological, Kruje, year of the reference 2012 
Table 2. Degree days; the territorial distribution of sunny hours, Albania; average daily radiation; National Agency of Natural Resources

\begin{tabular}{|c|c|c|c|c|c|c|c|}
\hline \multirow{3}{*}{$\mathrm{Nr}$} & \multirow{3}{*}{ City } & \multicolumn{6}{|c|}{ Threshold } \\
\hline & & \multicolumn{2}{|c|}{15.5} & \multicolumn{2}{|c|}{17.5} & \multicolumn{2}{|c|}{20} \\
\hline & & Degree days & Nr. Days & Degree days & Nr. Days & Degree days & Nr. Days \\
\hline 1 & Ballsh & 1128 & 190 & 1535 & 216 & 2115 & 247 \\
\hline 2 & B.Curri & 2131 & 209 & 2594 & 228 & 3235 & 252 \\
\hline 3 & Berat & 1130 & 187 & 1536 & 213 & 2110 & 242 \\
\hline 4 & Bilisht & 2369 & 243 & 2878 & 265 & 3570 & 286 \\
\hline 5 & Burrel & 1571 & 209 & 2012 & 232 & 2628 & 259 \\
\hline 6 & Cerrik & 1211 & 186 & 1607 & 205 & 2169 & 237 \\
\hline 7 & Corovode & 1325 & 200 & 1748 & 223 & 2344 & 252 \\
\hline 8 & Durres & 863 & 175 & 1244 & 204 & 1797 & 237 \\
\hline 9 & Elbasan & 1131 & 190 & 1537 & 215 & 2113 & 246 \\
\hline 10 & Erseke & 2374 & 251 & 2897 & 271 & 3599 & 288 \\
\hline 11 & Fier & 1068 & 188 & 1473 & 215 & 2055 & 248 \\
\hline 12 & Gjirokaster & 1358 & 200 & 1773 & 221 & 2362 & 249 \\
\hline 13 & Gramsh & 1246 & 195 & 1661 & 218 & 2245 & 248 \\
\hline 14 & Himare & 637 & 158 & 997 & 190 & 1532 & 222 \\
\hline 15 & Kavaje & 1126 & 193 & 1507 & 219 & 2134 & 252 \\
\hline 16 & Konispol & 1095 & 193 & 1507 & 218 & 2089 & 246 \\
\hline 17 & Koplik & 1316 & 190 & 1721 & 213 & 2287 & 238 \\
\hline 18 & Korce & 2273 & 240 & 2774 & 260 & 3453 & 281 \\
\hline 19 & Kruje & 1401 & 207 & 1842 & 232 & 2458 & 259 \\
\hline 20 & Krume & 2133 & 222 & 2605 & 245 & 3255 & 270 \\
\hline 21 & Kucove & 1033 & 182 & 1425 & 208 & 1984 & 238 \\
\hline 22 & Kukes & 2008 & 215 & 2462 & 238 & 3093 & 264 \\
\hline 23 & Lezhe & 1054 & 183 & 1451 & 211 & 2019 & 242 \\
\hline 24 & Librazhd & 1468 & 204 & 1900 & 226 & 2503 & 254 \\
\hline 25 & Lushnje & 909 & 174 & 1287 & 202 & 1833 & 234 \\
\hline 26 & Lac & 1134 & 183 & 1538 & 209 & 2113 & 240 \\
\hline 27 & Permet & 1338 & 195 & 1752 & 218 & 2331 & 246 \\
\hline 28 & Peshkopi & 2220 & 228 & 2698 & 249 & 3354 & 273 \\
\hline 29 & Pogradec & 1968 & 229 & 2450 & 251 & 3114 & 277 \\
\hline 30 & Puke & 2390 & 243 & 2896 & 262 & 3576 & 281 \\
\hline 31 & Reshen & 1551 & 202 & 1988 & 225 & 2591 & 253 \\
\hline 32 & Sarande & 595 & 151 & 930 & 182 & 1432 & 217 \\
\hline 33 & Shkoder & 1285 & 190 & 1692 & 215 & 2264 & 242 \\
\hline 34 & Tepelene & 1174 & 189 & 1580 & 214 & 2150 & 241 \\
\hline 5 & Tirane & 1128 & 189 & 1534 & 214 & 2110 & 243 \\
\hline
\end{tabular}




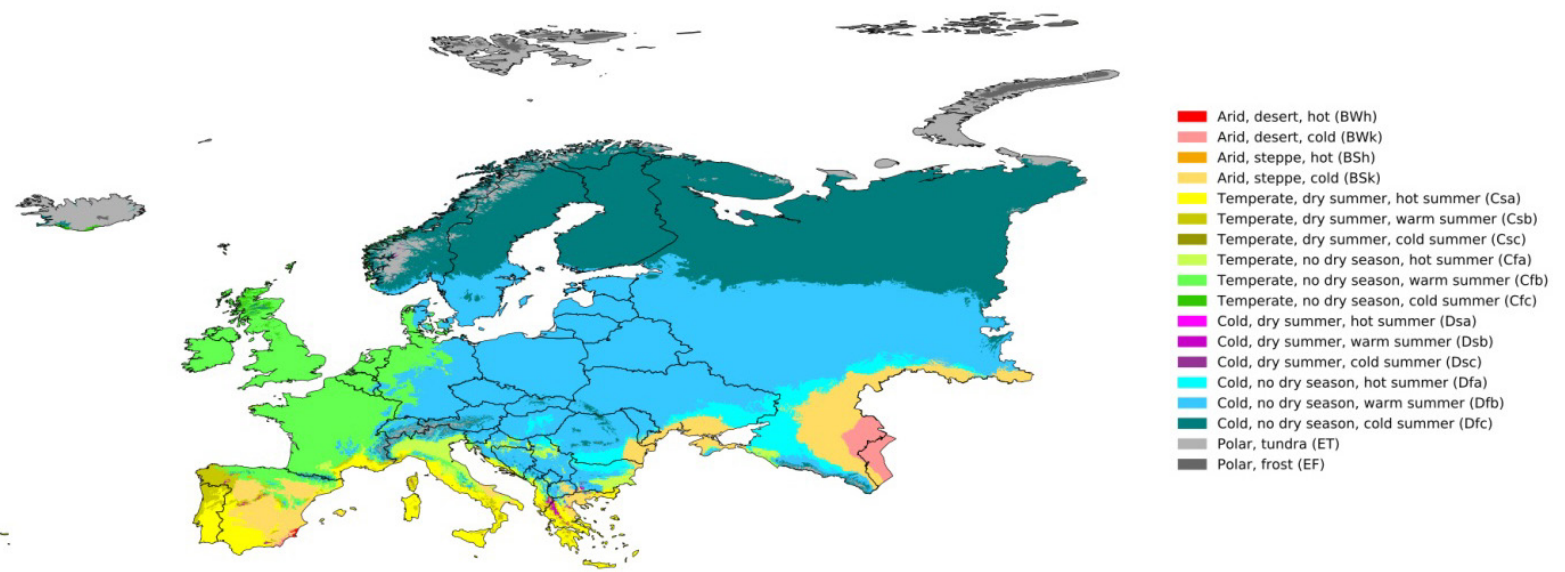

Figure 2. European climate; Koppen-Geiger climate classification map for Europe (1880-2016)
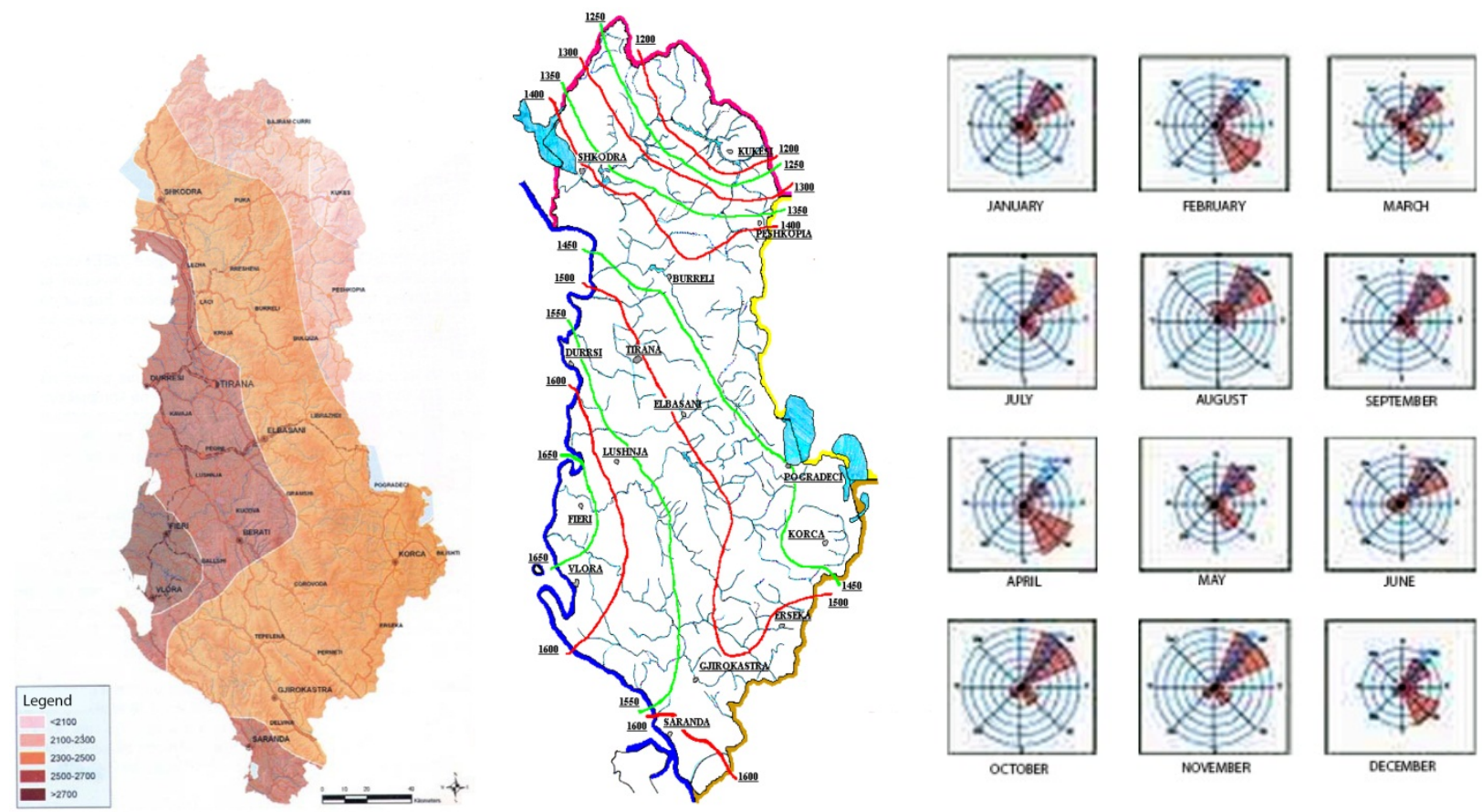

Figure 3. The wind rose of Kruja City for 12months; Science Academy, Institution of Hidro-meteorological, Kruje, year of the reference 2012

Kruja has an attitude of $560 \mathrm{~m}$ over the sea level and a latitude of 4130 . The studies have shown that the precipitation in the city of Kruja is around $1700-2000 \mathrm{~mm}$ per year. From this quantity $60-65 \%$ is infiltrated in the mountains of lime and the rest $35-40 \%$ flow along the slope of the mountain. The snow falling 2-3 times per year, in December and January, with a thickness of $10-30 \mathrm{~cm}$, and takes around two days to melt [1].

The degree days are one of the most important elements for the calculation of energy consumption used in the heating period. Degree day's calculation is performed on the meteorological database (the period of the survey 1961-1990). Determining the internal temperature, threshold is made by technical and economic solutions. The above table shows the degree days for different temperatures and the number of days when the temperature is below this threshold [1].

According to the winds rose survey noted a high percentage of the winds in the north-east direction with a percentage of over $60 \%$ and with $25-30 \%$ the winds in the sud-est direction [1].

\subsection{Historical Context}

The name of the city is related to the Albanian word "kroi" meaning "fountain". The castle of Kruja was built during the 5-th and the 6-th century and extended to a town probably from the sixth to the ninth century AD. In 1190 Krujë became the capital of the first autonomous Albanian state of the middle ages, the Principality of Arbër [2]. 
From 1450 until 1477 Krujë was defended successfully by the Albanian troops four times against the Ottoman army. Throughout the Albanian Revolt of 1912, that led to the creation of the Albanian Vilayet and later the Declaration of Independence of Albania. The city of Kruja, was one of the major anti-Ottoman centres. Following the
Italian invasion of Albania the country became a protectorate of the Kingdom of Italy. In the end of November 1944, the last German troops stationed in the area were defeated and LNÇ battalions entered the town [2].

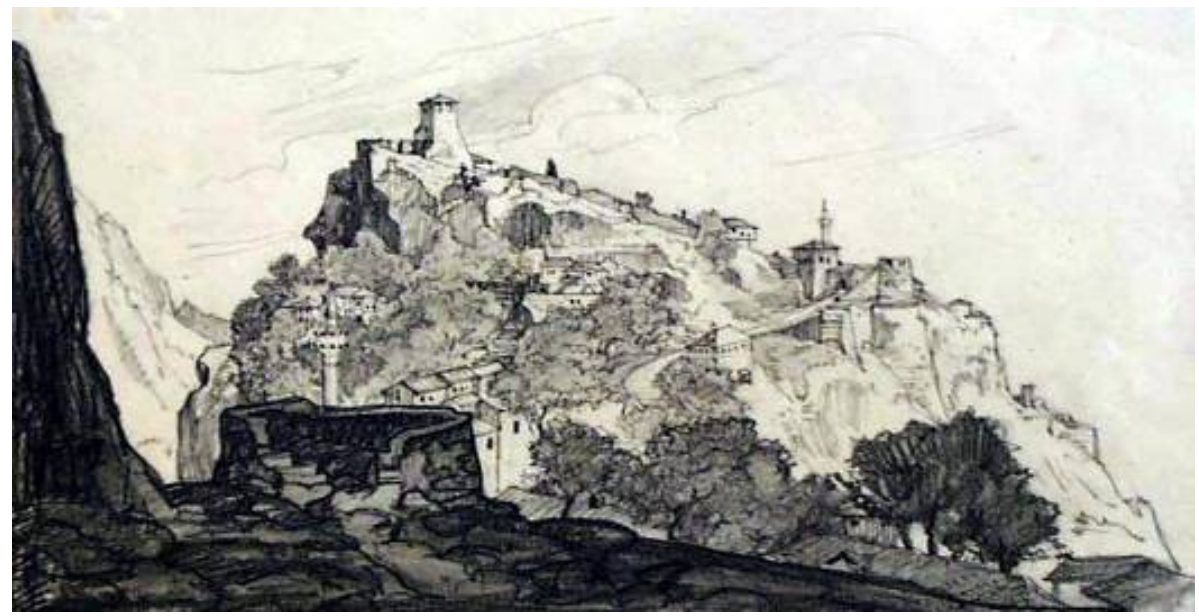

Figure 4. The citadel of Kruja during the middle ages [3]

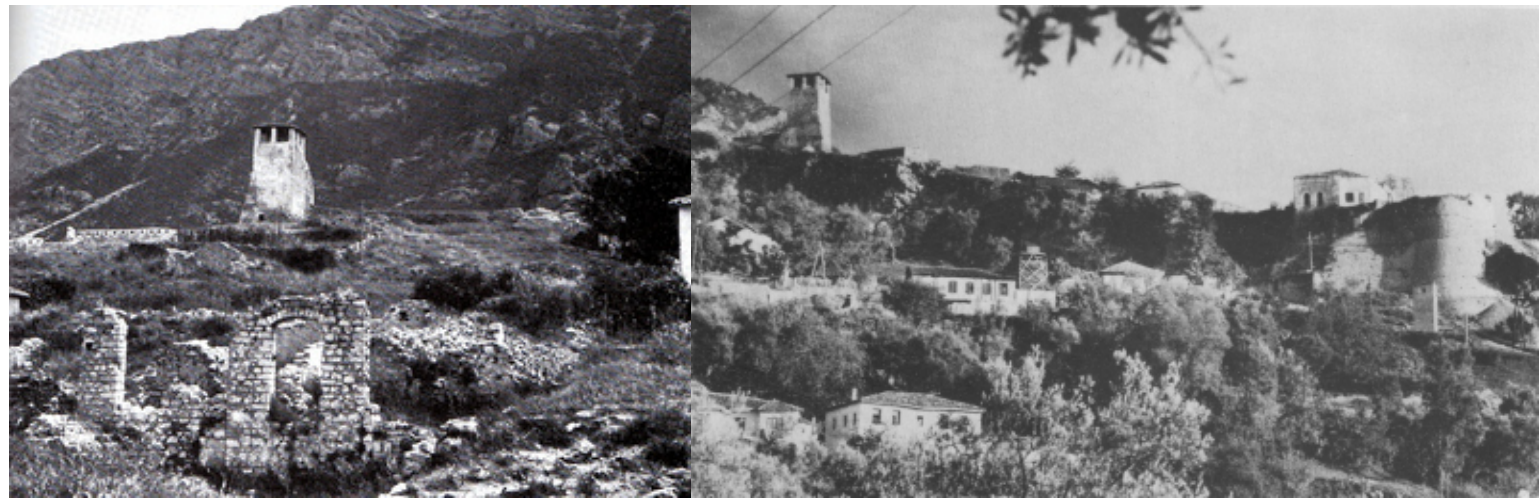

Kruja 1974

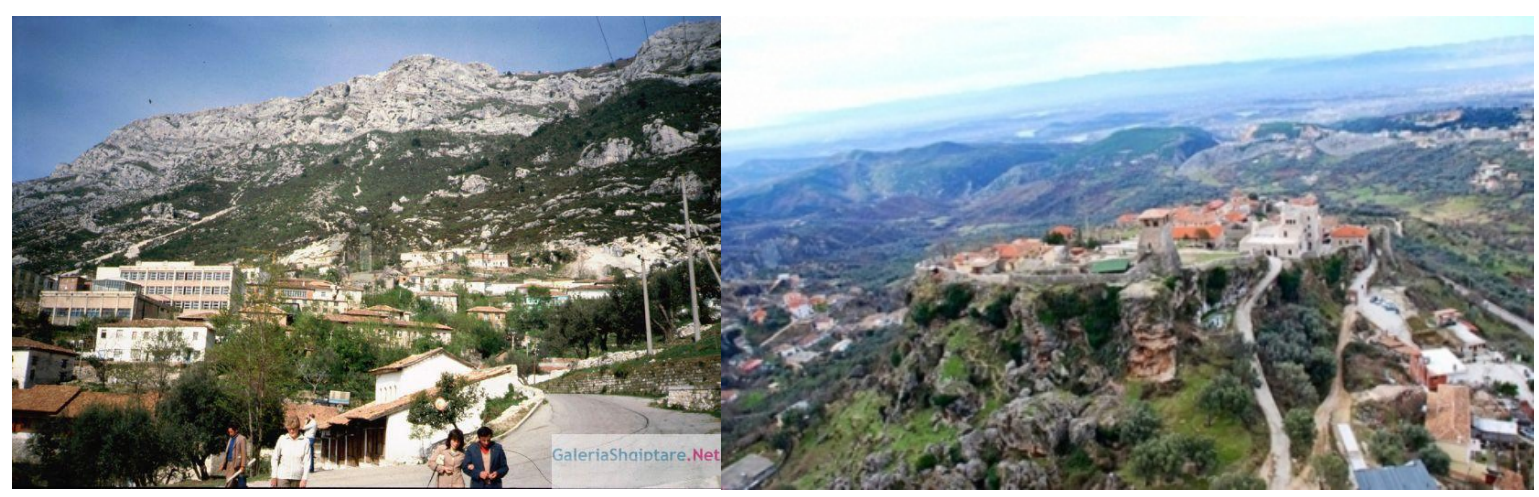

Kruja 1989

Figure 5. Photos through years [4] 


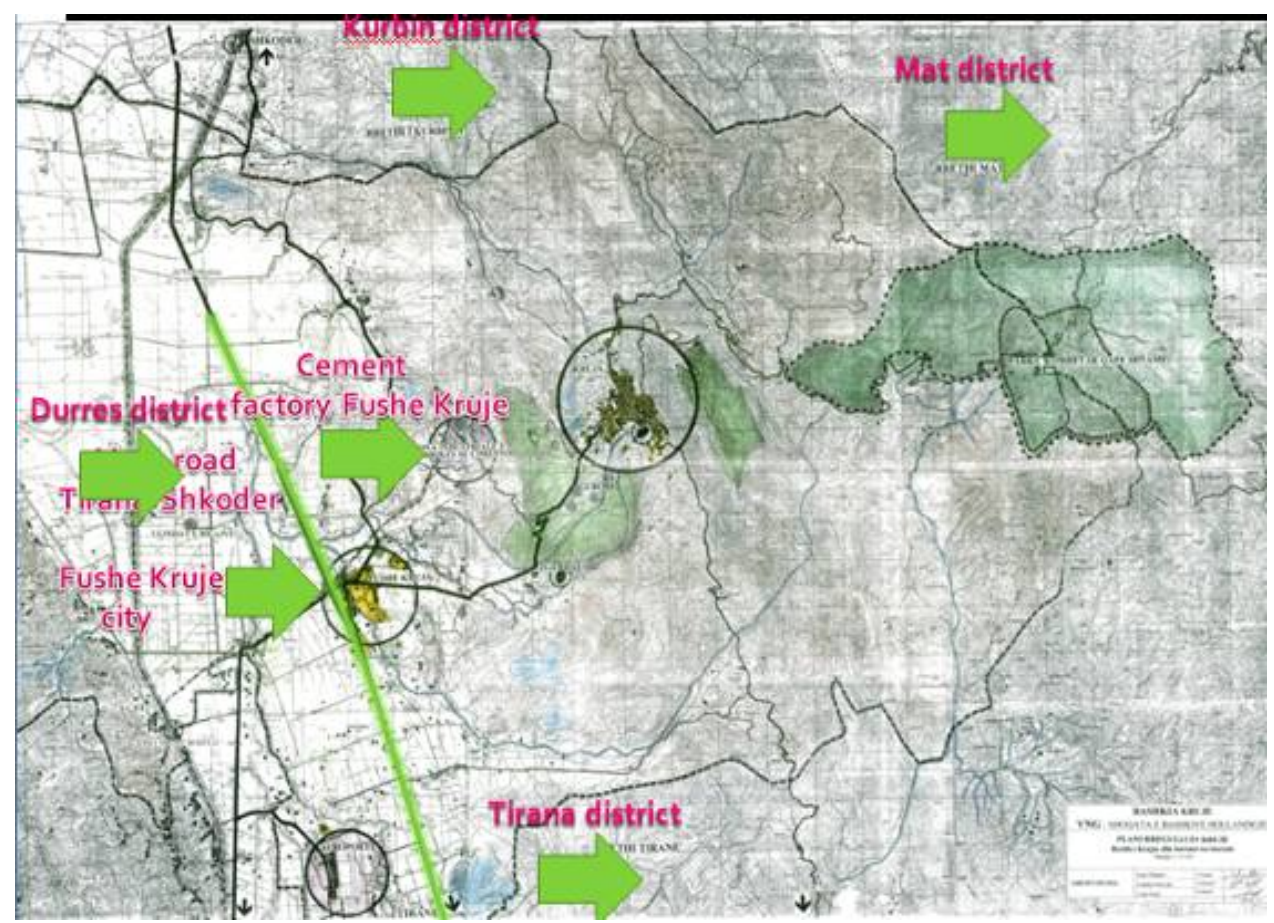

Figure 6A. Kruja district and its territory resources; Municipality of Kruja, Albania

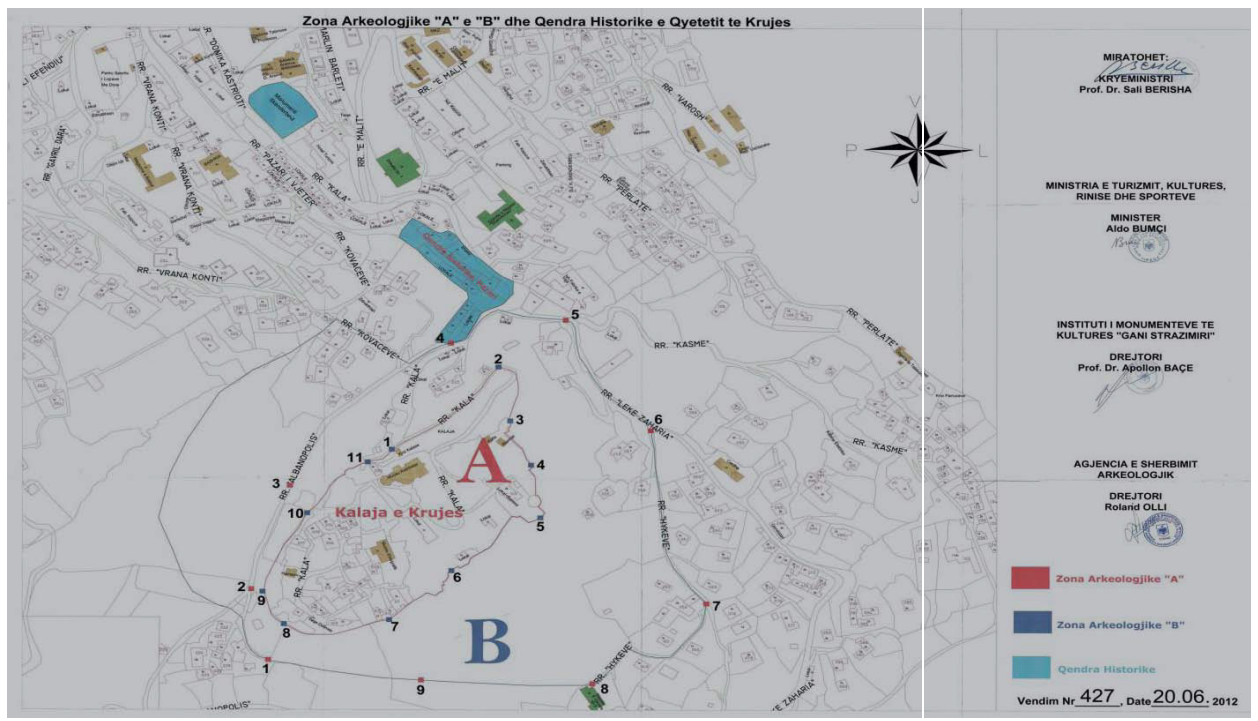

Figure 6B. Archaeological sites of Kruja [5]

\subsection{Archaeological Sites of Kruja, Albania}

Archaeological site "A" is allowed: Restoration and conservation of monuments; Reconstruction of the road and all the network engineering; Setting light construction (wood, glass, plastic, metal) with maximum height $3 \mathrm{~m}$. The project is approved by the National Council of Archaeology and the National Council of Restoration.

Archaeological site " $\mathrm{B}$ " is allowed new construction after written approval by the National Council of Archaeology. Construction is allowed only after conducting preliminary Archaeological Service Agency intensive observation, archaeological surveys or other forms of testing. Testing format is defined by the Archaeological Service Agency, but mostly are surveys that do not affect the layers in case of continuing archaeological excavation. In cases when during the implementation of construction project revealed findings of particular importance, the project should be reviewed [5].

\subsection{Motivation}

The need for clean energy is growing day by day worldwide. Learning about the revolutionary sustainable communities, building materials, techniques of 
construction, new smart materials, conservation of the energy, acquisition of the energy, current supply and demand for energy, annual energy consumption, are important factors that nowadays must be taken into consideration. The main goal is to collect all the necessary materials and all the necessary philosophies in order to make an improvement of the way of life of Kruja's people, based on the relevant questionnaires.

Energy and people lifestyle is an integral factor of how we live, work and play, in order to understand future changes in energy demand we need to understand the dynamic nature of how our changing lifestyle interact with the built environment [6].

The importance of building characteristics has been determined in diverse studies. Leth Petersen and Togeby [7] studied the influence of building regulations on energy use, finding that they have been important in reducing energy consumption in new buildings. As a consequence, overall energy use associated with building characteristics is decreasing, making the role of the occupant even more important.

Studies have shown that occupant behaviour might play a prominent role in the variation in energy consumption in different households [8], [9] but the extent of such influence is still unknown.

\subsection{Objectives}

Understanding the correlation between the different building typology and Kruja's people lifestyle is important.

The main goals are well defined and are very connected not just with the general analyse of the historical city of Kruja but also they are much related to the building typology, their facades, their materials, their orientation, their energy consume and to their human resources. The aim of this study is to create a wellbeing environment and to understand the different human behaviour in different house typology in the city of Kruja, Albania.

This study aims to gain greater insight into the effect of occupant behaviour on energy consumption by determining its effect on the variation of energy consumption in dwellings and social impact of the occupancy in different house typology, while controlling the building characteristics. In addition, this study aims to determine the respective effect of building and occupant attributes on energy use, and the relationship between them. Occupant behaviour in some cases is determined by the type of dwelling.

\subsection{Past Research and Documentation}

In the last decade, a big attention was given to the energy efficiency. According to the International Energy Agency, global energy demand will grow $55 \%$ by 2030 . In the period up to 2030, the energy supply infrastructure will require a total investment of 26 trillion USD, with about half of that in developing countries [10].

Many recent reports on energy efficiency on building stress that occupant's behaviour is one of the most important aspect to archive energy efficiency buildings.

Worldwide, the building industry and the built environment are some of the largest contributors to energy and material use. In the northern part of the European Union, $41 \%$ of total final energy consumption comes from buildings, with $30 \%$ being used in residential buildings [11]. According to EuroAce [12] (57)\% of the energy consumed in buildings is used for space heating, $25 \%$ for hot water, $11 \%$ for lighting and electrical appliances, and $7 \%$ for cooking.

The Europeans has now European National Laws that have to be complied by new buildings. However, there is also a growing concern about the existing buildings, especially about the possibilities to modernize them, making them more efficient.

Many recent reports on energy efficiency on building stress that occupant's behaviour is one of the most important aspects to archive energy efficiency buildings: "the behaviour of building occupants can have as much impact on energy consumption as the efficiency of the equipment" [13]. Heightened energy consumption awareness is expected to stimulate behavioral changes both at household and enterprise level [14]. A smart building is only as smart as the people ruining it.

\section{Methodology}

The questionnaire data was obtained as the basic unit for analysis (year of reference of the questionnaires 2015). There are three types of dwellings in the city of Kruja: historical ones, socialist ones and modern ones. For each category of building was undermined a questioner of 30 questions and for each category were asked 15 persons of different gender and age. Graphics are built based on the sum of the answers to three categories. The graphs are designed for analysis purposes and to draw conclusions related to the general trend for all categories. 


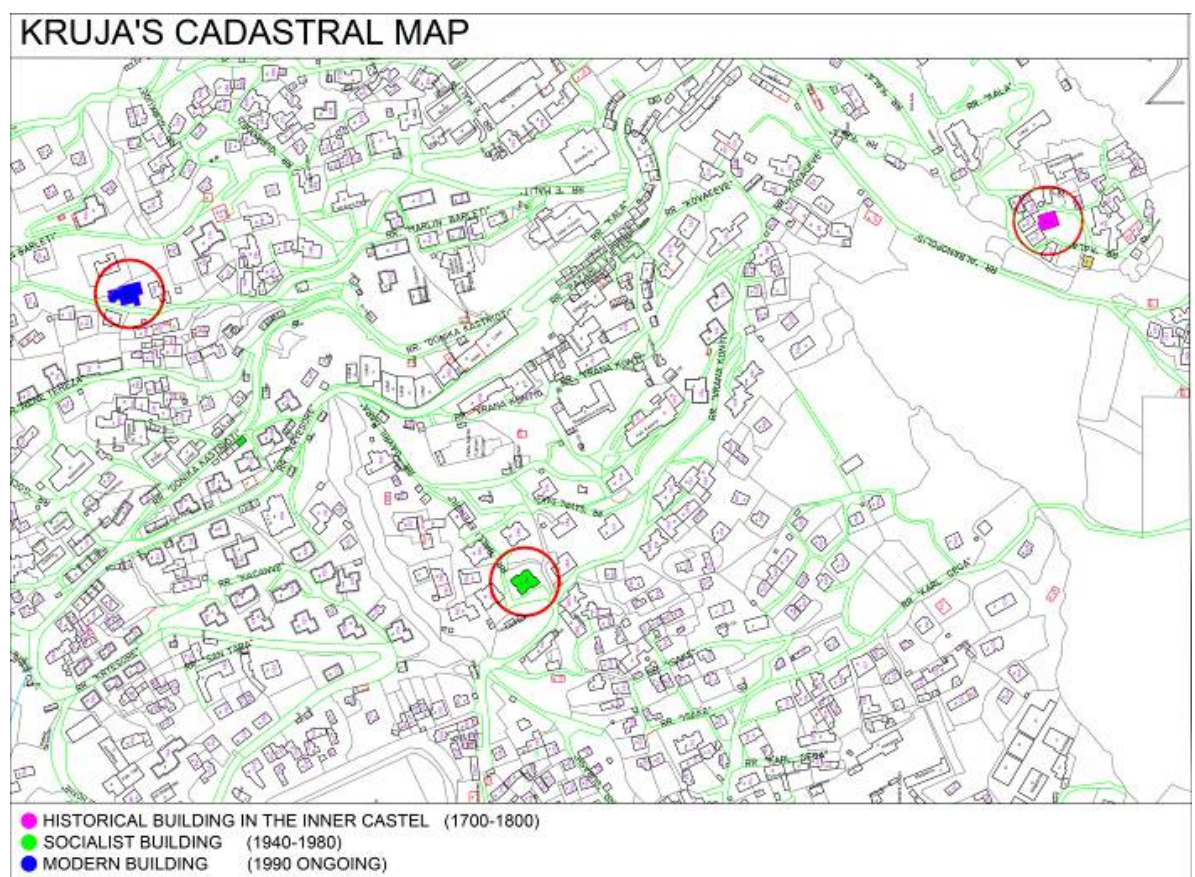

Figure 7. Cadastral map of Kruja; Municipality of Kruja

The historical ones are located in the inner citadel. The socialist ones are located mostly in the centre of the city and the modern ones mostly in the outskirts and also in the centre of the city. All of them date in different periods of time. This is a very good indication of the development of the city in time.

The historical buildings are positioned in the citadel which dates from XI century and some of the buildings where reconstructed after a big fire in the XVIII century, preserving the old ruins. The questionnaire is mostly focused in the chosen position of the building (in the inner citadel).

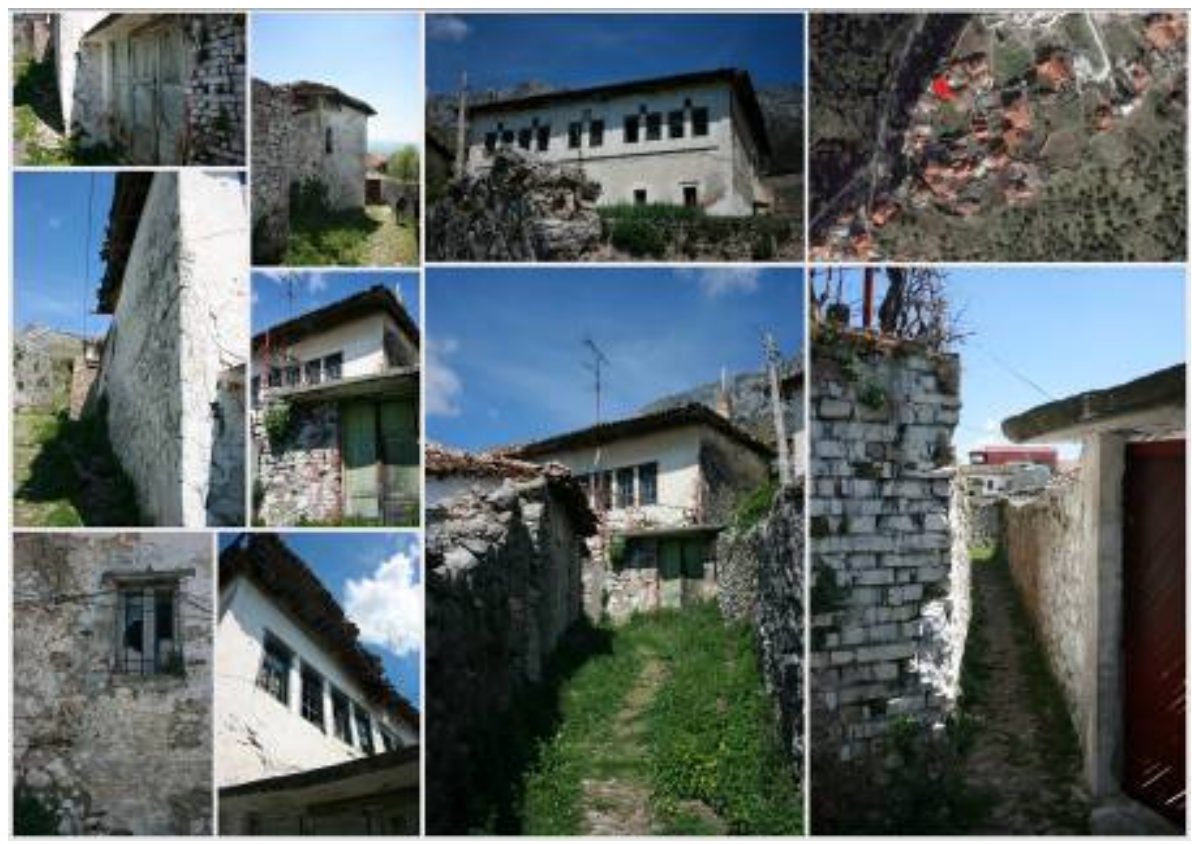

Figure 8A. Medieval building dating from 18-century, Photos of the existing situation; Klodjan Xhexhi 

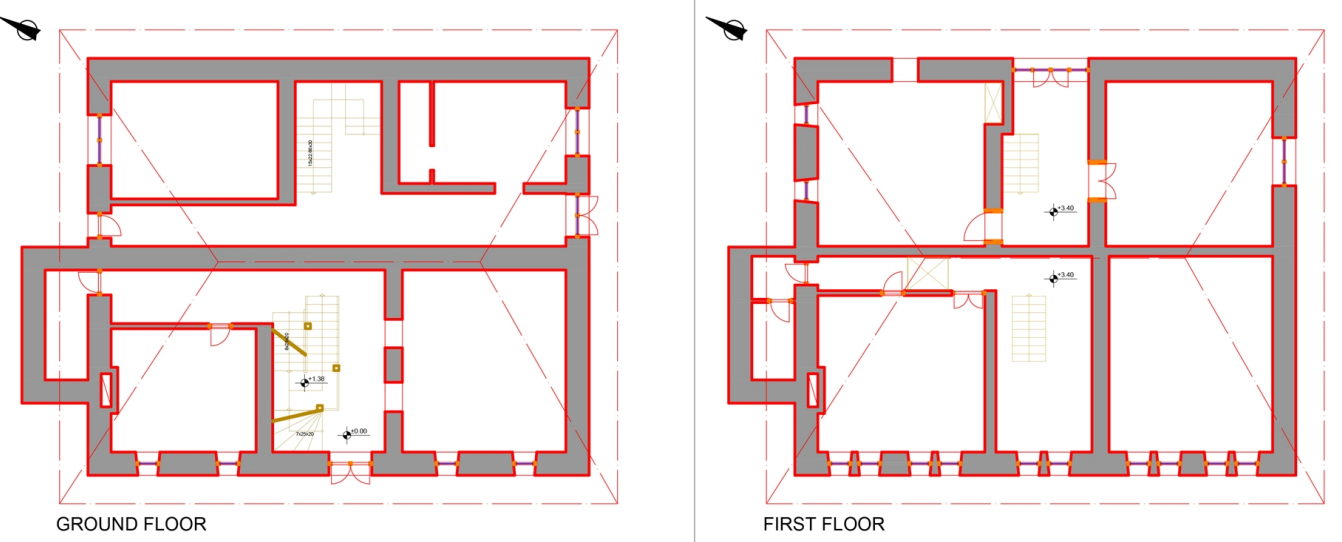

Figure 8B. Medieval building dating from 18-century, Plans; Klodjan Xhexhi
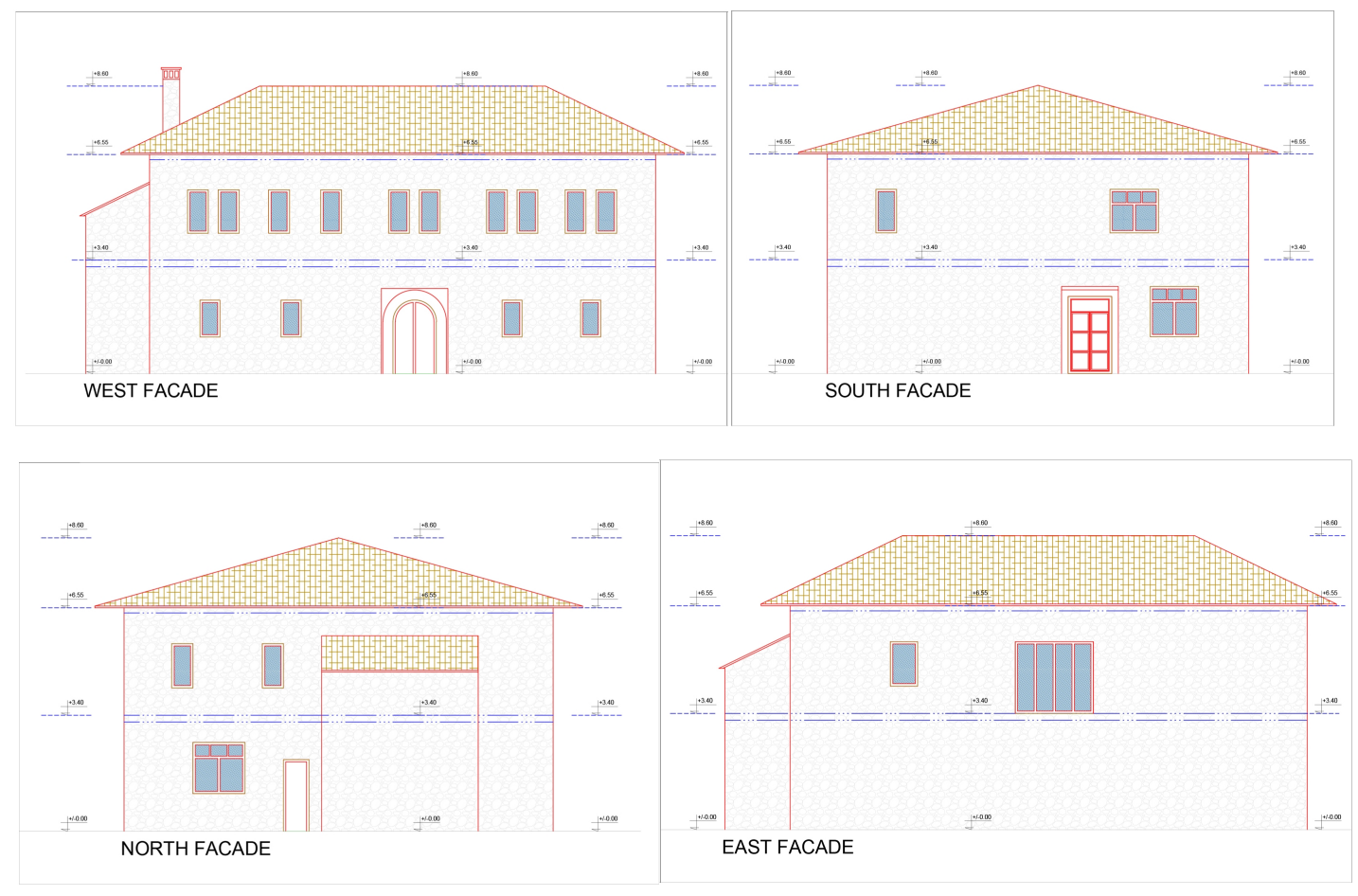

Figure 8C. Medieval building dating from 18-century. Facades; Klodjan Xhexhi

Socialist buildings are dating from the second half of the 20-century. The typology is spread all over the city. The questionnaire is mostly focused in the chosen position of the building. 

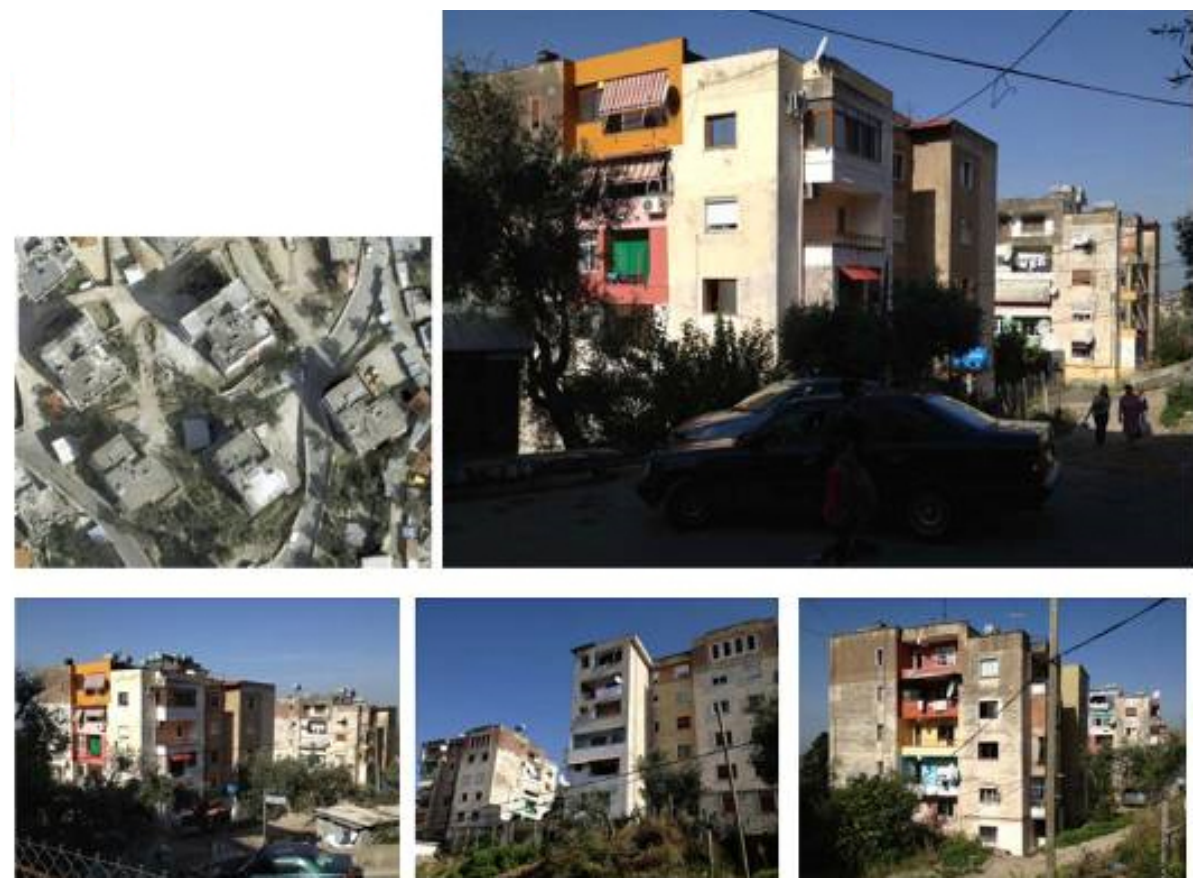

Figure 9A. Socialist building dating from the second half of the XX century, Photos of the existing situation; Klodjan Xhexhi

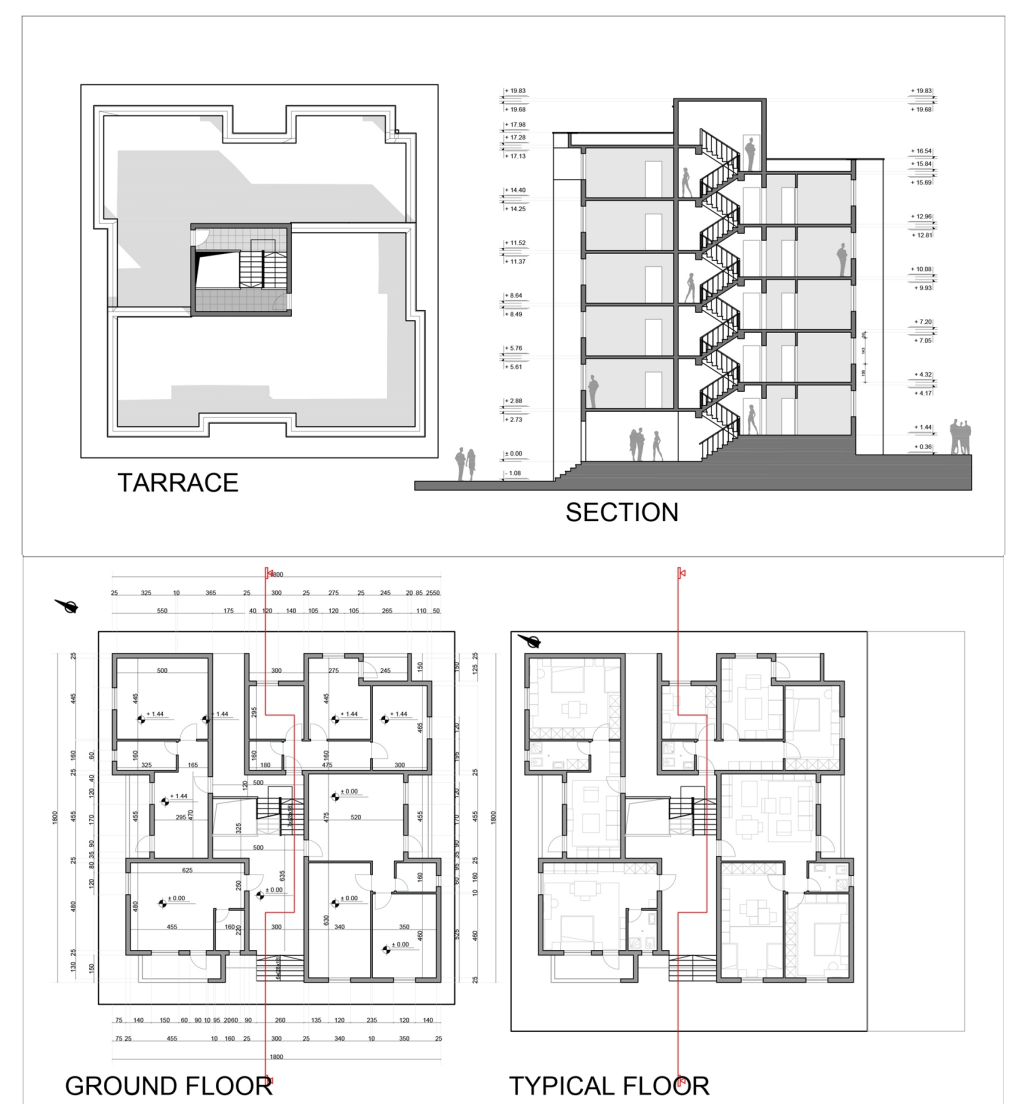

Figure 9B. Socialist building dating from the second half of the XX century, plans, section; Central Technical Building Archive of Albania

Modern buildings are dating from the 1990 ongoing. These typology is also spread all over the city. Sometimes ruining the city silhouette. The questionnaire is mostly focused in the chosen position of the building. 


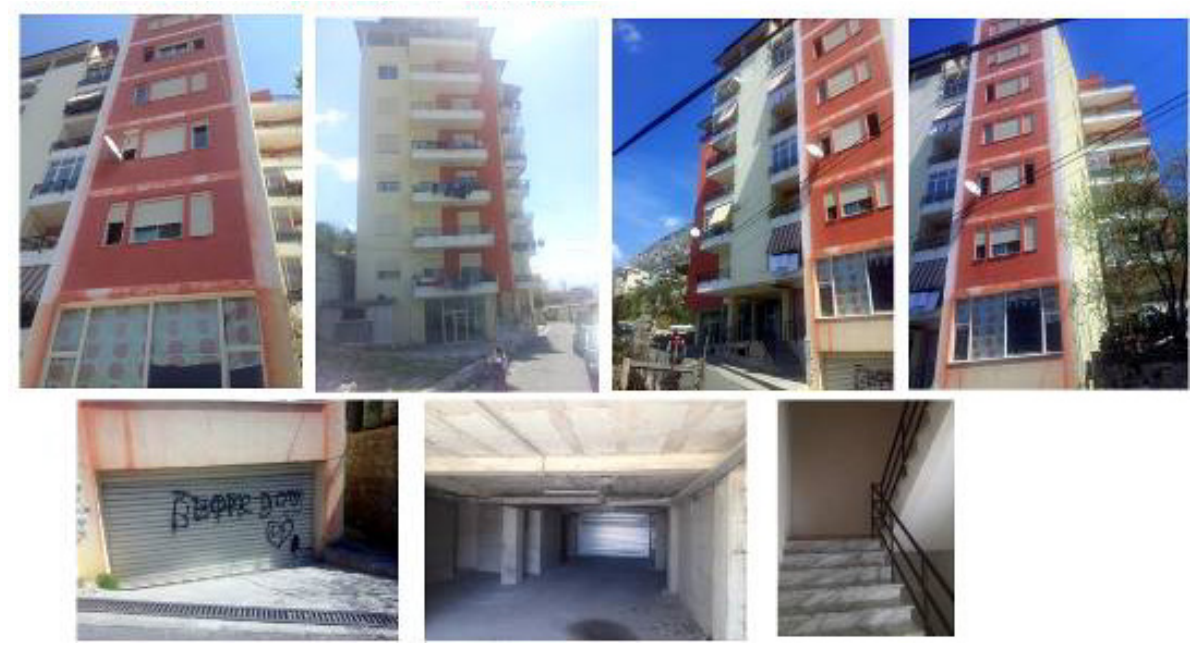

Figure 10A. Modern building dating from the 1990 ongoing; photos of the existing situation; Klodjan Xhexhi

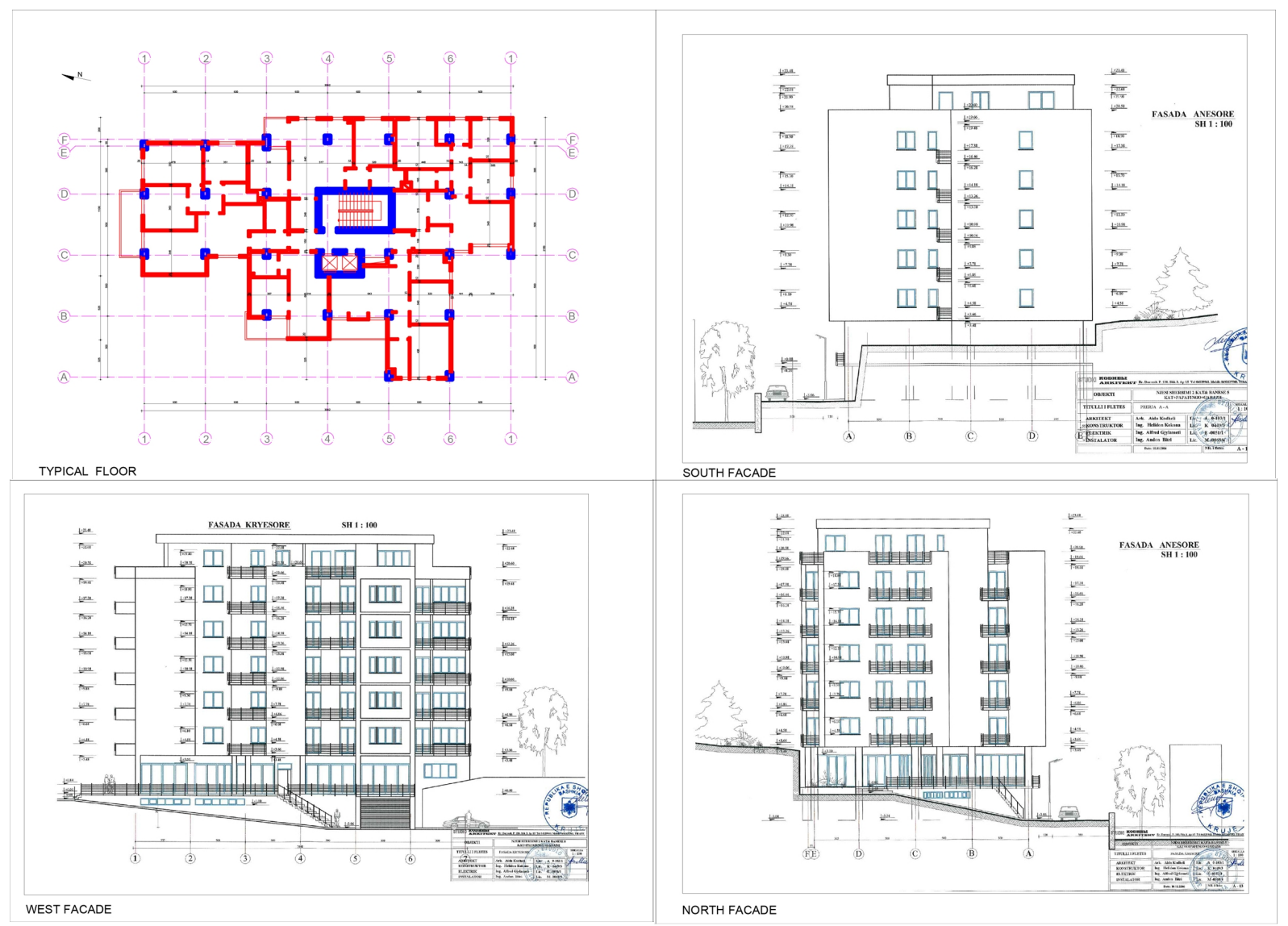

Figure 10B. Modern building dating from the 1990 ongoing; plans, facades; Municipality of Kruja, Albania 


\section{Questionnaire and Interpretation}

The graphical process and interpreting of the questionnaires requires attention and logic interventions.

Historic buildings have the largest number of residents, but it should not be forgotten that historic buildings also have larger living spaces (inhabitant/square meter). However, the tendency as a result of this question is declining. The most disadvantaged buildings in this case are the socialist ones that have the smallest living spaces per inhabitants in comparison with the other categories, despite the fact that the number of residents is the same as in the modern dwellings. Historic buildings are characterized by large families composed of several generations mostly three of them living in the same dwelling. Meanwhile the other categories are mainly composed of a single family maximum of 4 inhabitants (Figure 11A).

Logically the families with the greatest history and the most lifelong ones are the historic dwellings. The linear trend also in this case is declining from the historical buildings to the youngest age of modern dwellings dating back to 1990 .

The chart besides the age of the dwellings also shows a kind of loyalty mostly of the residents to the historical dwellings, despite the bad housing conditions (Figure 11B).

Historic buildings have the largest living areas compared to the other two categories. Despite the fact that the number of rooms (+living room) per apartment is the same as for socialist and modern dwellings, the modern ones have more residential living space that the socialist ones. In some isolated cases in modern apartments are sometimes included 3 bedrooms + living room. The chart trend is declining again with a tendency of rising in the future. The most disadvantaged category in this case is that of socialist dwellings (Figure 12A).

Chart no. 4 shows that residents are not very sensitive to temperature differences. Their answers show a lack of understanding of optimal thermal comfort level (Figure 12B).
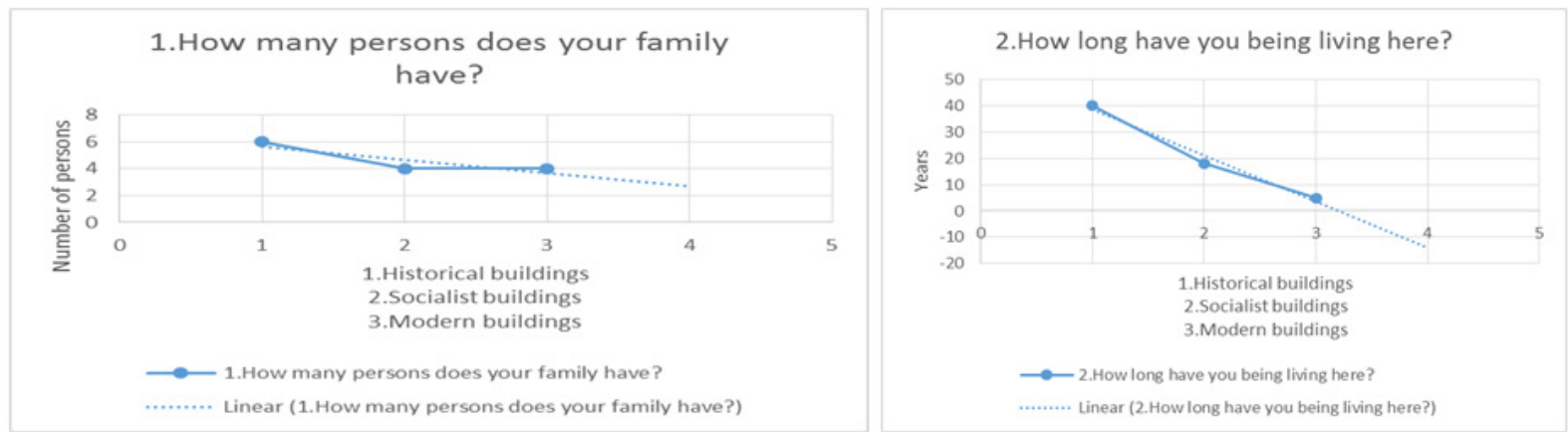

Figure 11A. Number of persons in the family; 11B. Time of living in the dwelling
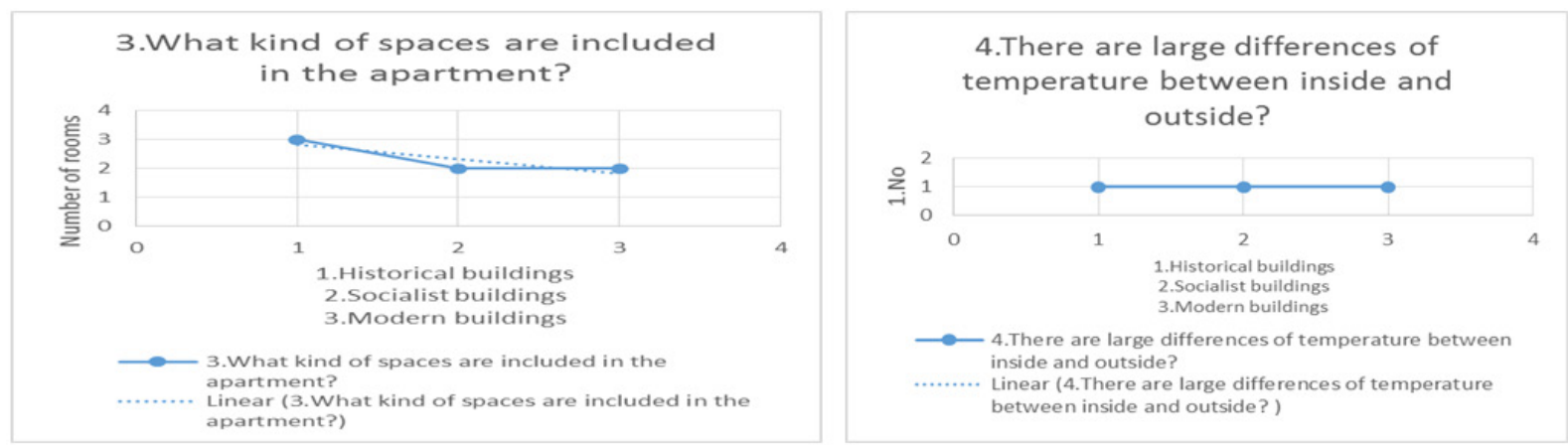

Figure 12A. Housing typology according to the number of rooms +living room; 12B. Temperature differences between inside and outside 


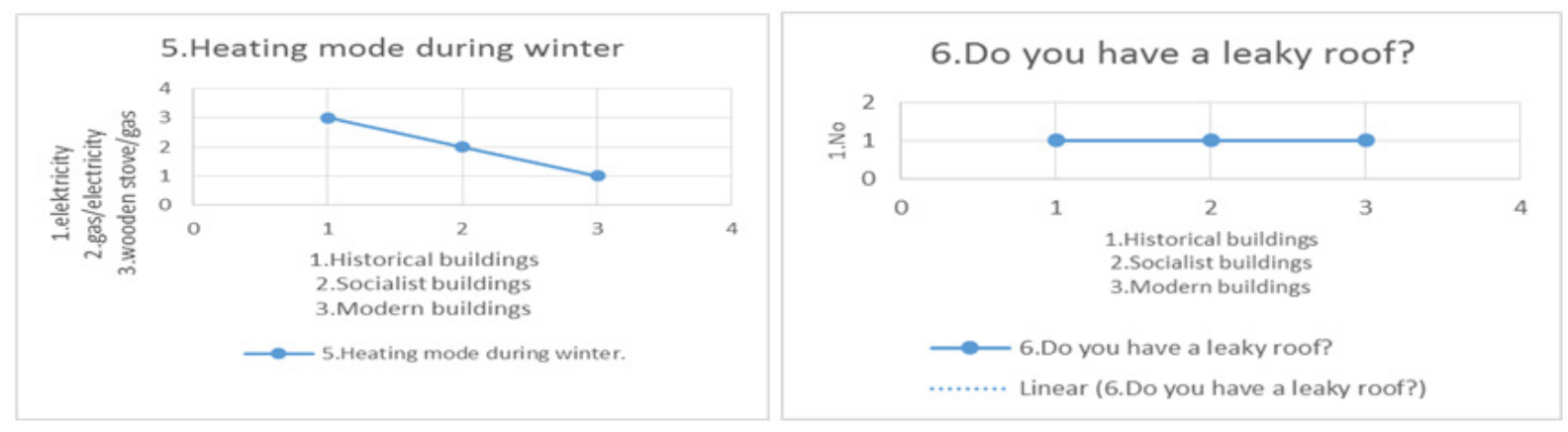

Figure 13A. Heating mode during winter; 13B. Roof leaking problems

The graph shows a radical transformation of the method and the heating devices, from wooden stoves (phase 1; historic buildings) to electricity (phase 3; modern buildings). As the catalyst of the transition from phase 1 to phase 3 is gas used for heating which is simultaneously also more economical than the other two variables. The situation shows also the transitory phase of the Albanian economy over the years (Figure 13A).

Meanwhile all three categories have no problems with roof leaks but some of them do have problems with the humidity. Minor problem related to the issue have the historical ones. Residents of historic buildings tend to maintain their roofs in a relatively good condition (Figure 13B).

According to some authors, occupant behaviour affects energy use to the same extent as mechanical parameters such as equipment and appliances [17], causing variations in energy use as large as a factor of two in similar dwellings with identical equipment and appliances. In an empirical study of 600 households in Sweden, Linde'n et al. [18] found that households living in detached houses have to accept lower indoor temperatures than households living in flats. In addition, they found that for households living in dwellings where the energy bill is paid collectively, the indoor temperature is higher by about $2{ }^{\circ} \mathrm{C}$, indicating that the differences are more likely to be due to occupant behaviour than to building characteristics.

Considerable problems with humidity have historical and socialist buildings. These are inherited problems which are attributed to poor building materials, poor isolation and amortization over time. The trend in this case is improving in favour of the modern buildings.

Precautions should be taken in consideration to improve the moisture levels of the more problematic buildings, especially in areas that have direct contact with the sloppy terrain (Figure 14A).

Referring to the refreshment method in the summer period it is important to note that the historic buildings are again in the lead compared to the other categories. Residents prefer to open just the window than to use the air blower (fan) or other air conditioning systems. This indicates that historic dwellings are closer to comfort zone that the other categories. Building materials, physic characteristic of the buildings (such as wall thickness, roof, height of the floor) and occupant behaviour, in this case play a major role in providing a thermal comfort near the optimum comfort zone. The economic well-being of the inhabitants is another fact to take into consideration. Most of them cannot afford the costs of using air conditioning in their dwellings (Figure 14B).

Comfort cannot be absolutely defined, something can be said about the physiological limits within which humans operate. At the most basic level, there is evidence of a lessening of physical and psychological distress when hard-to-heat housing in the UK is improved to provide a basic standard of ventilation and warmth (Henwood, 1997). This standard is normally taken to be the one set by the World Health Organisation: $21^{\circ} \mathrm{C}$ for people in a living room and $18^{\circ} \mathrm{C}$ elsewhere in the home [15].

Studies have shown that occupant behaviour might play a prominent role in the variation of energy consumption in different households but the extent of such influence is unknown [16]. Air infiltration and ventilation are very important factors. In thermally efficient buildings these become the dominant thermal loss mechanism [19].

Some studies suggests that ventilation from windows accounts for a large percentage of the ventilation rate in occupied dwellings [20]. Iwashita and Akasaka undertook ventilation measurement in Japan. According to them there are large differences between the mean ventilation rate during occupancy and non-occupancy (doors and windows closed) and that a large percentage of the total air change rate $(87 \%)$ is due to the behaviour of the occupants [20].

In a German study was found that natural ventilation is more frequent in bedrooms, followed by children's rooms and living rooms. Is also found a correlation between ventilation habits, outdoor air temperature and wind velocity. Night time ventilation occurs less frequently than daytime ventilation [21]. 


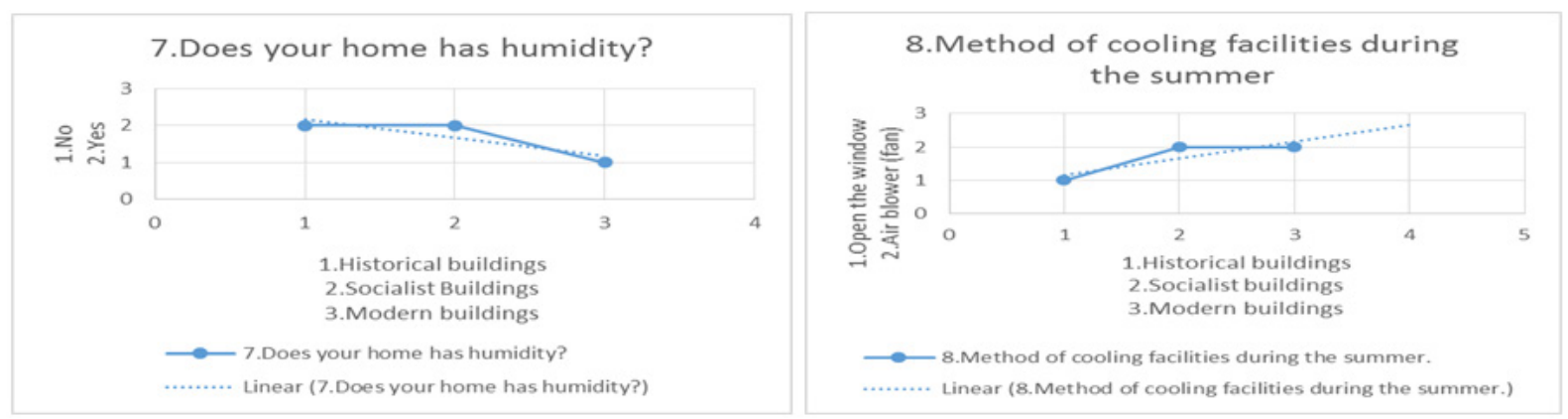

Figure 14A. Moisture problems; 14B. Method of cooling during summer

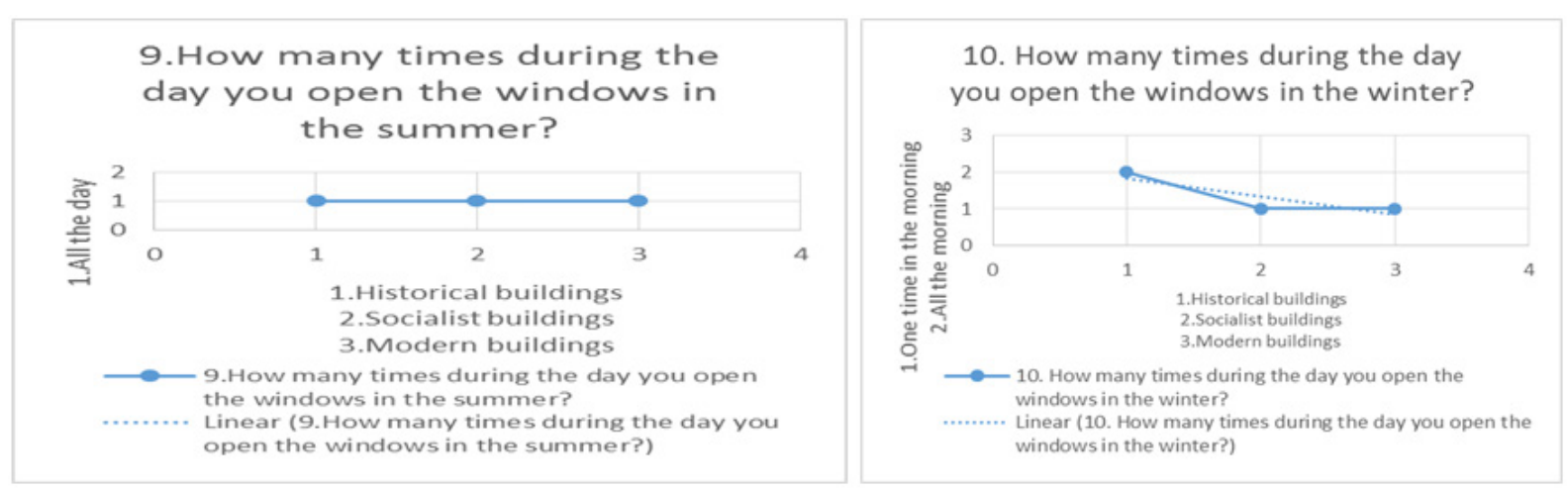

Figure 15A. Ventilation in the summer; 15B. Ventilation in the winter

According to the charts (Figure 15A; 15B) the interaction of residents with the outside environment is greater during the summer season. There are two reason: 1.Residens cannot afford the bill of the air conditioning system; 2.Residents do not have thermal comfort inside the dwelling. Meanwhile in the winter time they react with the outside environment mostly just in the morning. Residents ventilate their dwellings ones in the morning or all the morning. The residents cannot afford to ventilate the building twice a day in the winter time because they cannot afford the bills of heating the house during the winter.

The occupancy behaviour is relatively different for each category. The residents of historic buildings prefer to spend most of their time in the kitchen because they don't afford heating the entire dwelling. This is the main reason why they prefer mostly the fire room (kitchen). This fact has to do also with the historic Albanian tradition; where as the main daily space of living was the fire chamber. The transit area is represented by residents of socialist housing who prefer to unify the spaces in one. They prefer to spend most of their time in both spaces. This is also attributed to the minimalist living spaces according to the communist regime philosophy. The residents of the modern buildings prefer to spend most of their time in a modern way, in the living room. This is a clear expression of the metamorphosis, transformation and evolution of occupancy behaviour in the inner dwelling spaces in the city of Kruja (Figure 16A).

Residents with higher bills for water and consequently also for electricity are residents of socialist and modern buildings. This is due to the relatively higher incomes of these families. Residents of historic buildings pay fewer bills, because they include also alternative heating methods such as wooden stoves and gas (Figure 16B; Fig 17A). 


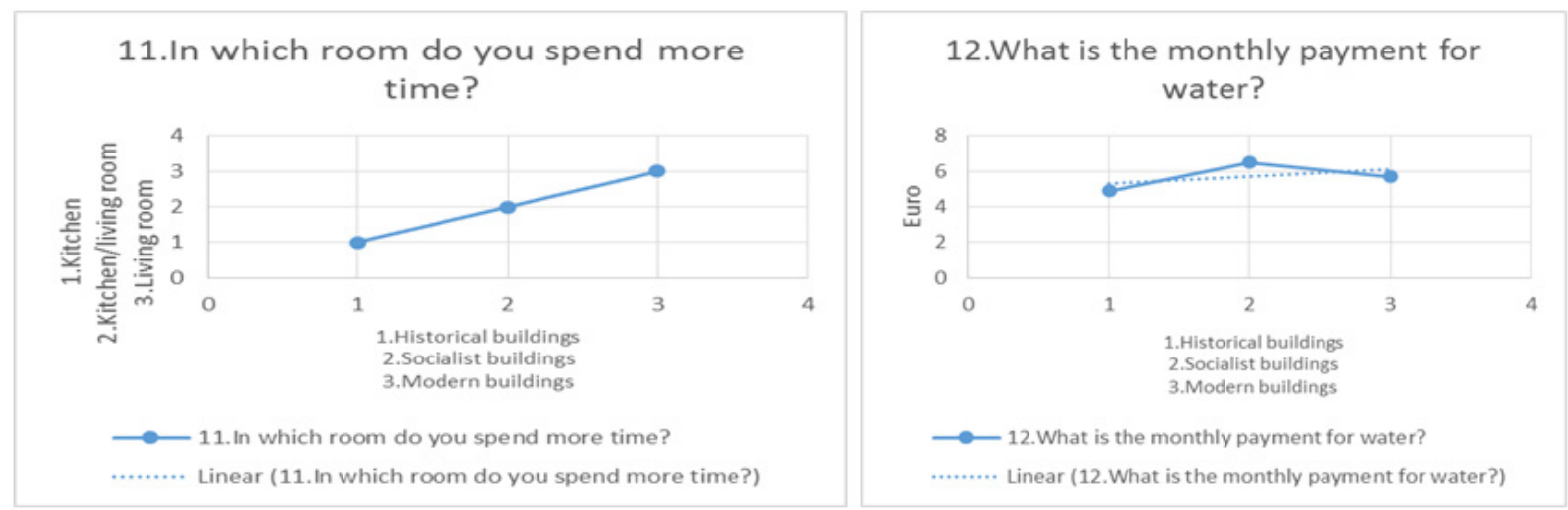

Figure 16A. Time spent in the apartment; 16B. Monthly payment for water

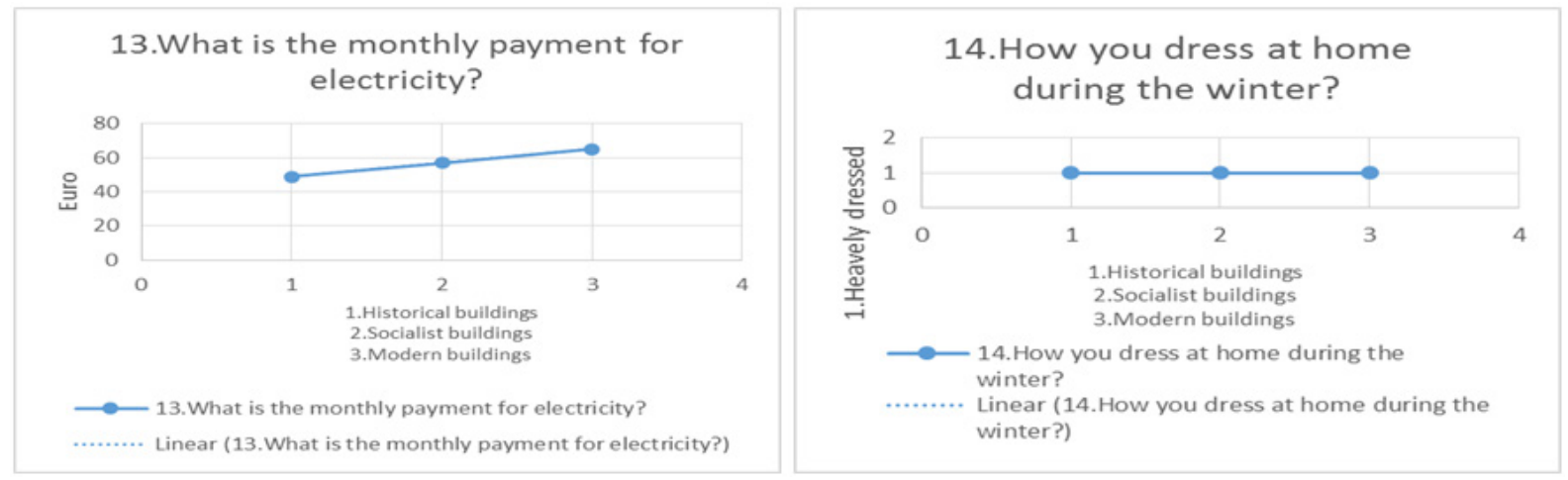

Figure 17A. Monthly payment for electricity; 17B. Manner of dress during winter

The dressing mode during winter and summer is another important issue to take into consideration. There are small differences of the occupancy behaviour in the winter time and in the summer time for the three typologies of buildings. During the winter the residents behaviour is the same despite the fact that they live in buildings with different physical parameters (Figure 17B). Relatively the same behaviour occurs during the summer season. The socialist and modern categories are more sensitive to the summer season. Responses are also much related to the age of the respondents. In historical buildings, the age of respondents is relatively higher than the other two typologies. This may be one of the reasons for the minimal differences in responses (Figure 18A).

The restoration of the buildings of the first two typologies is a necessity for the residents. They are in a very poor physical condition. The residents of these two categories have positively responded to this question. Their buildings need to be restored (Figure 18B).

The question of the presence of moisture in the dwellings has been duplicated using the terminology of house paint. Responses are logical and proportionate among them. If painting lasts longer in time less problems with moisture the buildings have. The winning category of this chart are the modern ones (Figure 19A).

Despite the fact that residents of historic buildings are happy with the current level of living this is not due to physical characteristics of the building. This is mainly attributed to their positioning in the inner historical citadel. Historic buildings have the advantage of numerous visits by foreign and local tourists so financial benefits are greater (Figure 19B). 

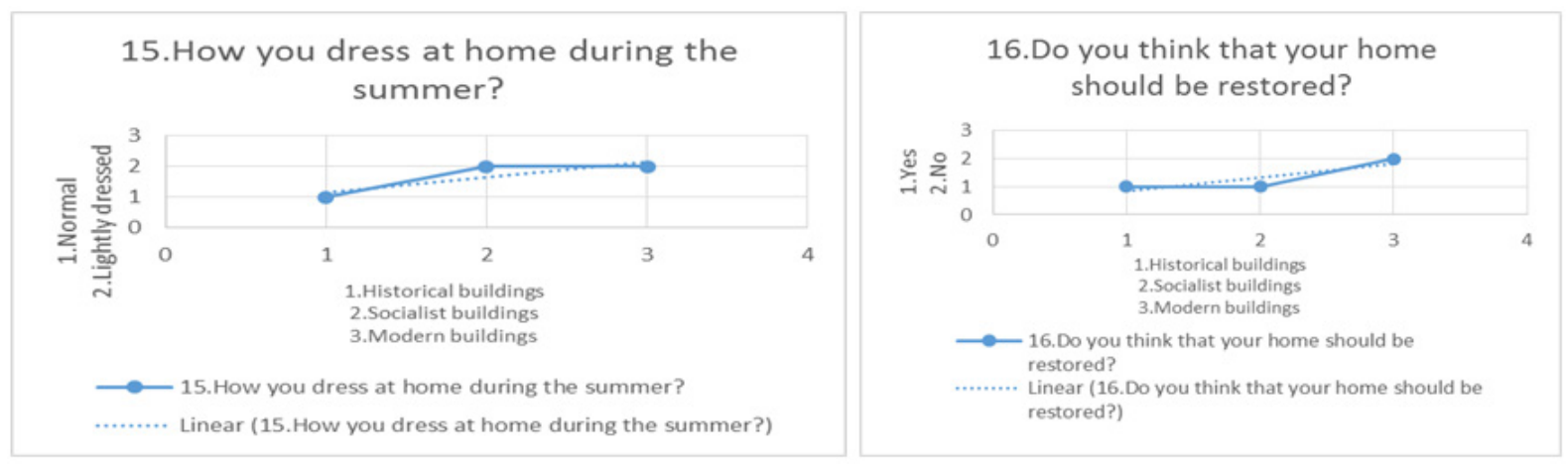

Figure 18A. Manner of dress during summer; 18B. The need for restoration
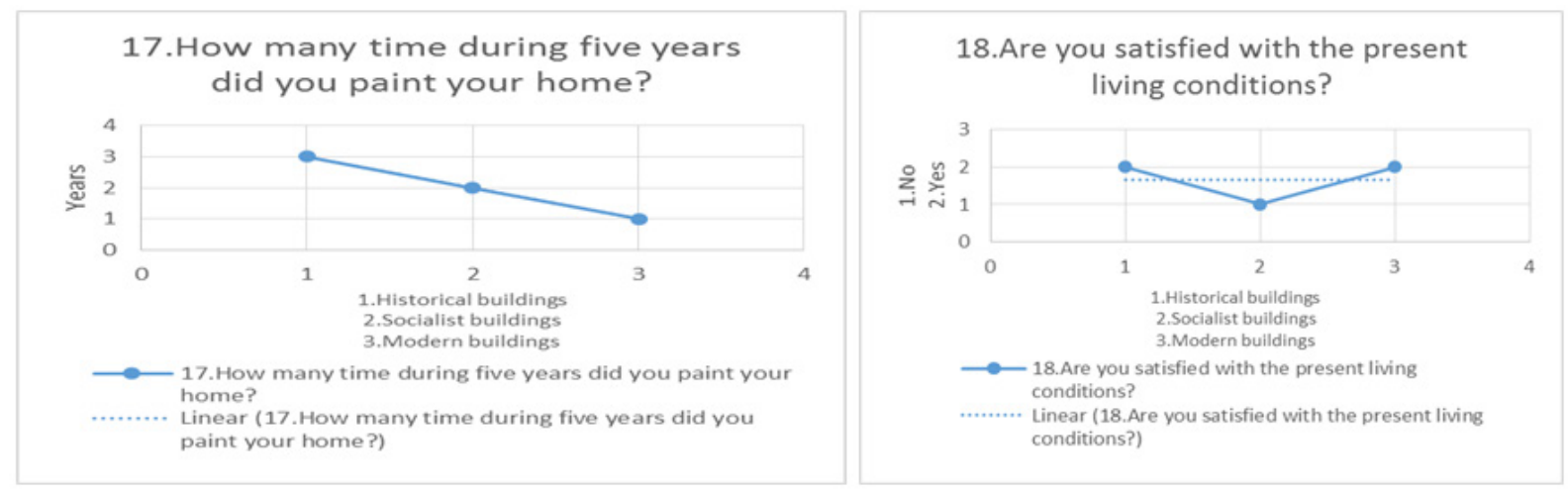

Figure 19A. The frequency of painting; 19B. Level of satisfaction

House improvements can be minimal or substantial. The category that needs significant changes is that of socialist buildings. The category requires more space which is very difficult to archive in the current situation in comparison with the other two categories. The requirements of the other two categories are mostly easier to achieve. Socialist buildings suffer from the lack of minimal living spaces. This is attributed to the communist philosophy of time for housing realization according to the logic of standardization and typification (Figure 20A).

The worst category which is not satisfied with the present living condition are the socialist buildings.
The most unsocial category seems to be again the socialist ones. The residents of these categories prefer to stay home most of the time or in the company of their family. Meanwhile the other two categories prefers more to socialize with the neighbours, friends and foreigners. They are relatively open as mentality (Figure 20B; 21A).

The buildings in the city of Kruja are mainly south-east oriented, because in the north of the city is located the mounting of Skanderbeg. The city enjoys a very beautiful panorama to the sea (Figure 21B). This is one of the reasons why most of the apartments are south-east oriented. 

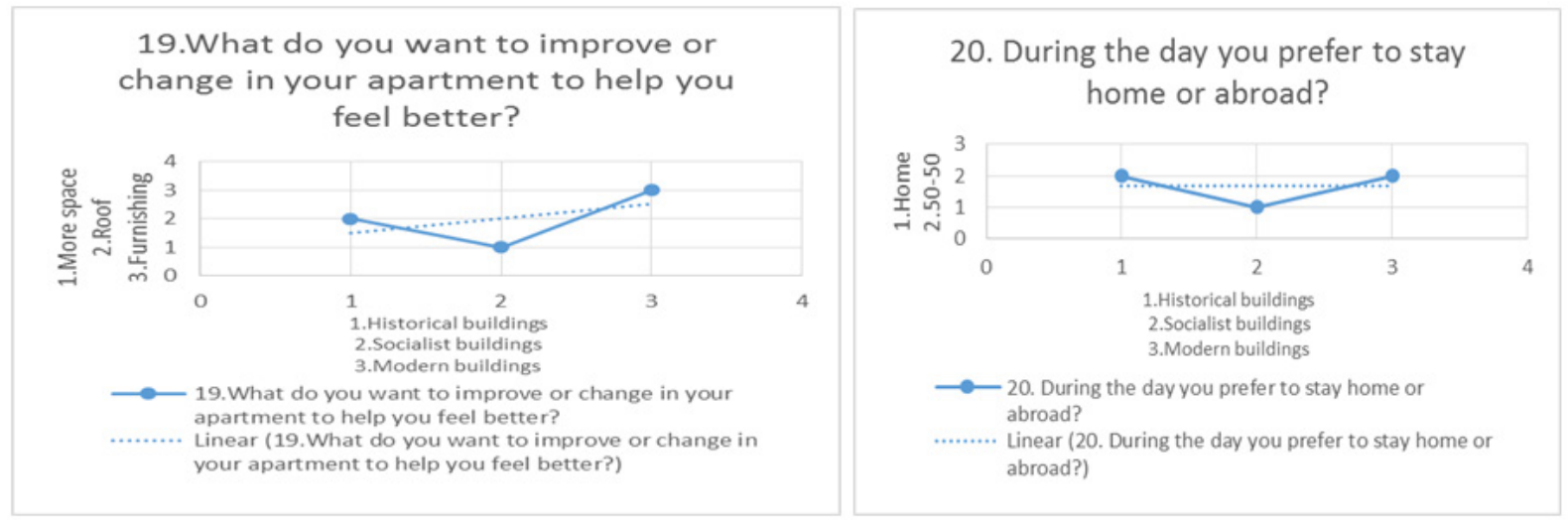

Figure 20A. The manners of improvement; 20B. Social interaction-home or abroad of the residents

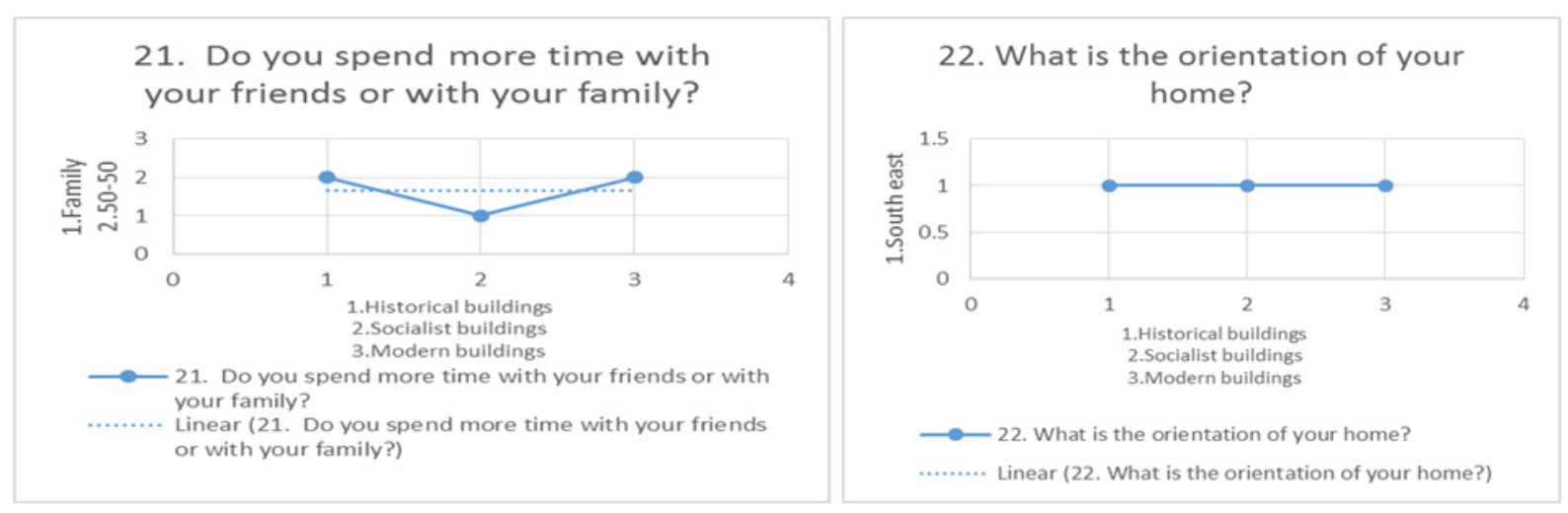

Figure 21A. Social interaction-time spending-family or friends; 21B. Orientation of the apartment (kitchen-living room)

The spent hours in the living room are in favour of historic and socialist buildings for two reasons: Lower employment rate and the age of the residents (more elderly than other categories), (Figure 22A).

The only category that requires changing the living place with a better one is again the socialist buildings. This emphasizes once again as the weakest the category. Residents of historic buildings despite their bad living conditions do not leave their dwellings. The dwellings in this area, despite the conditions, are coveted by all (Figure
22B).

Lighting bulbs are mostly economic ones, rarely led bulbs (modern buildings). This is attributed to their higher cost (Figure 23A).

The city of Kruja is a mountainous and quiet city and the level of noises is relatively low. The quieter buildings are the historical ones because they are positioned in the fortress. The lack of cars access roads increases the level of acoustic comfort (Figure 23B). 

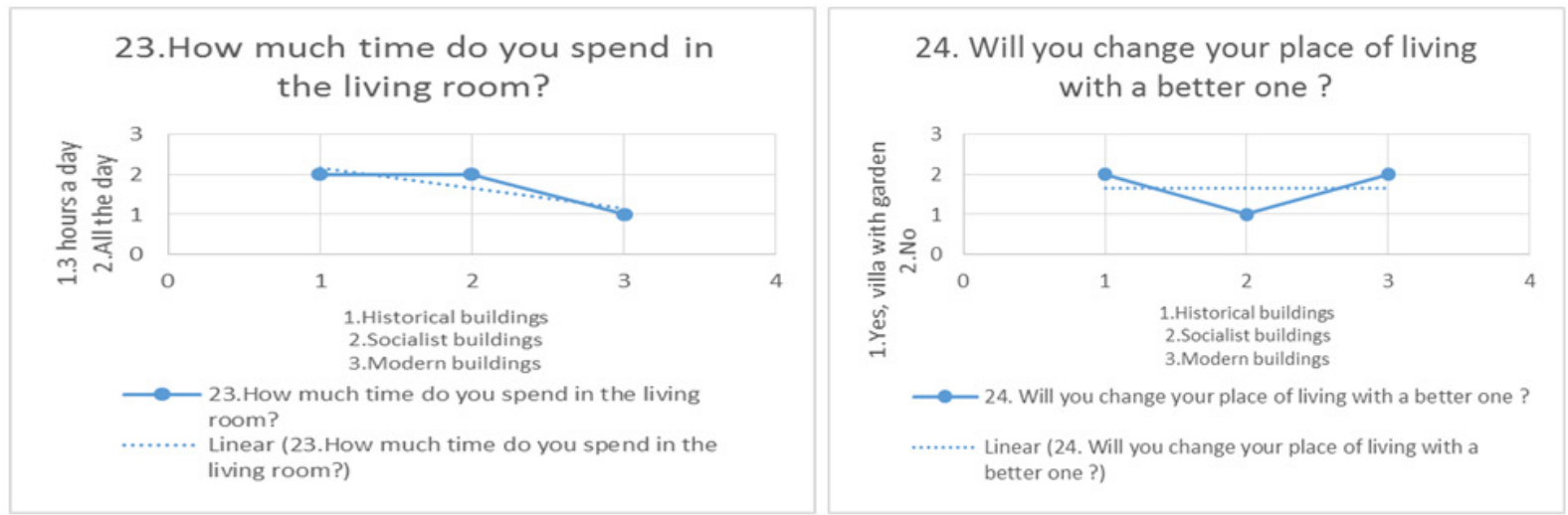

Figure 22A. Time spent in the living room; 22B. The need for change and improvement

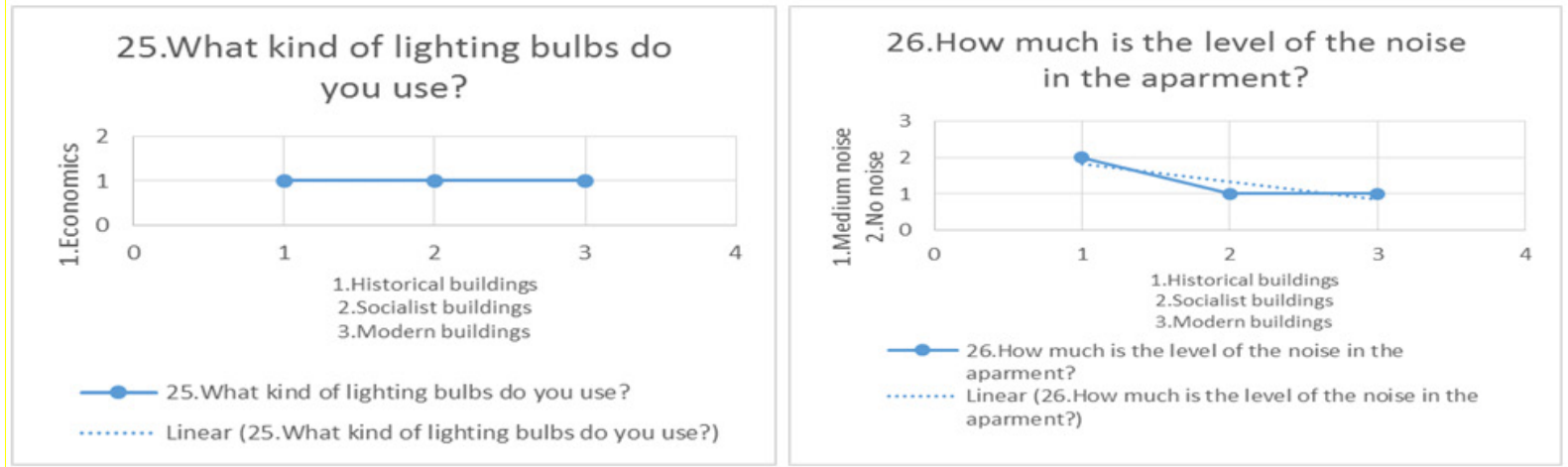

Figure 23A. Lighting bulbs typology; 23B. Level of noise

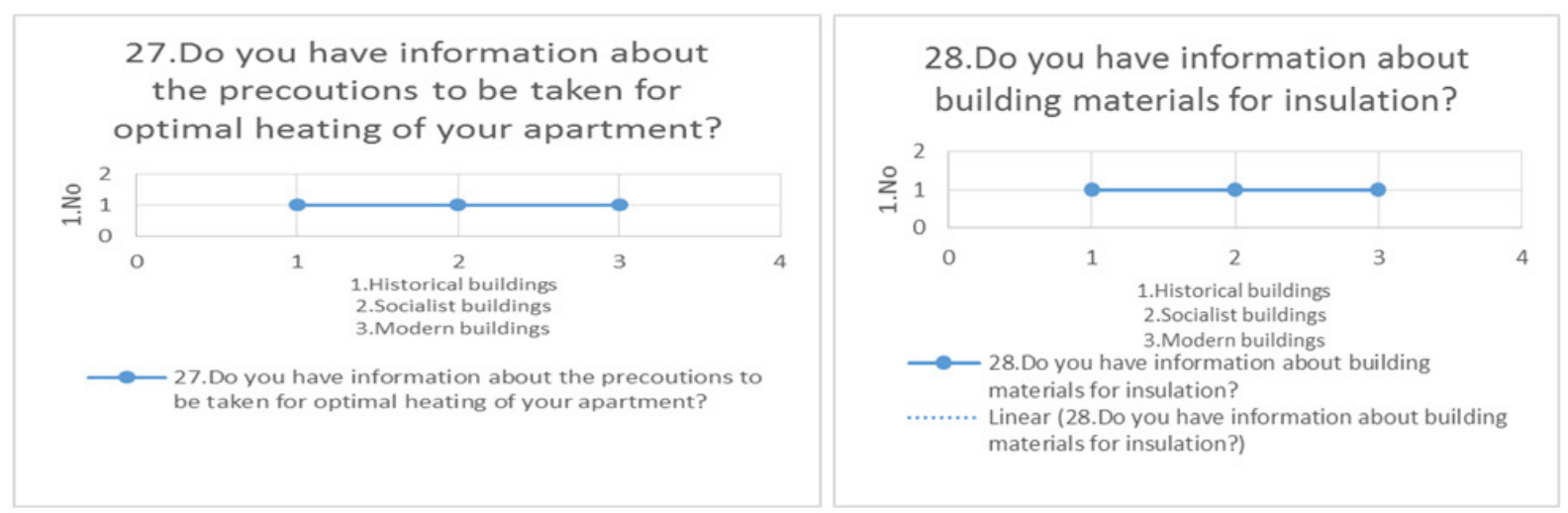

Figure 24A. Optimal heating precautions; 24B. Building materials for insulation
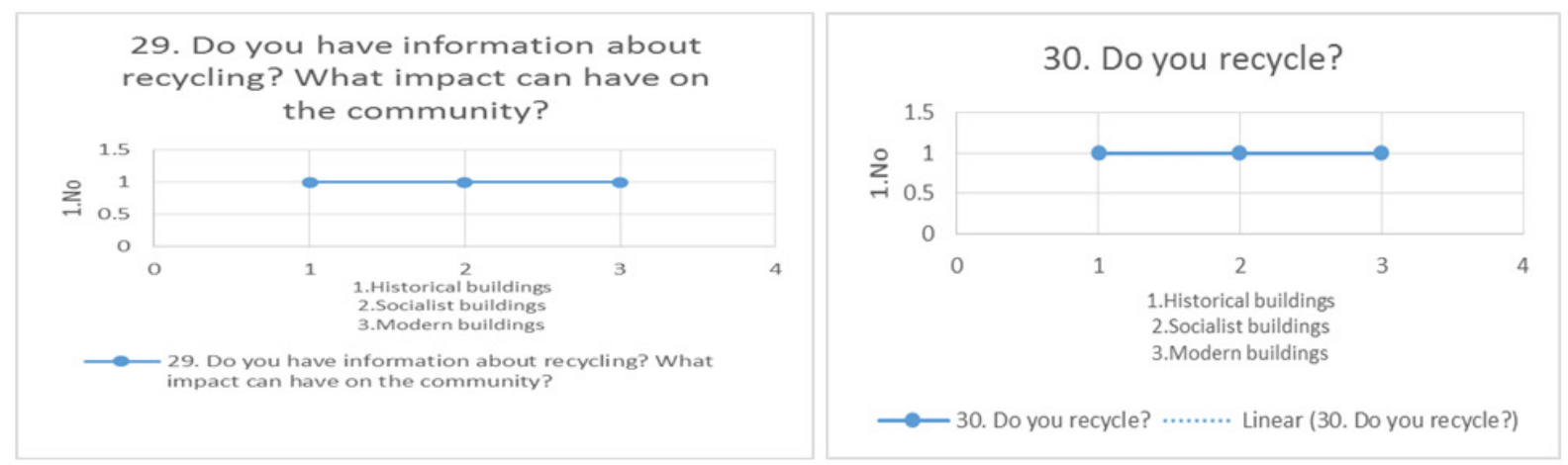

Figure 25A. Recycling and the community; 25B. Recycling 
Unfortunately the inhabitant does not have information, or poor information about the precaution to be taken for optimal heating, building materials for insulation, and recycling.

\section{Conclusions}

Although the conditions are not good people tend to get a high level of place attachment and loyalty to the building they are living.

Especially the inhabitants that are living in the historical site do not want to change the apartment, the main reasons is place attachment, the level of tranquility (inner peace) and the second one is related to the economical issues. They want to profit as much as possible from their property. The dwellings in this area, despite the conditions, are coveted by all. One of the reasons is the high number of tourists who visit it.

The weakest category appears to be the socialist buildings. The residents in this category are the unhappiest of all categories. Because of the poor conditions of living, poor insulation, lack of space, lack of other facilities, their tendencies are to leave the apartment heading to a better one. Oslo the most unfriendly category is this one which prefers not so socialize much as the two other categories.

The biggest energy consumers are the historical buildings and socialist ones, although the bills of the electricity are smaller than the third category they consume alternative energies and have major problems with thermal bridges.

Unfortunately the inhabitants of all the categories do not have any good information related to the building insulation materials and recycling instruments.

\section{REFERENCES}

[1] Institution of Hidrometereological, Kruje, year of reference 2012

[2] Google 2013: http://www.inyourpocket.com/albania/tirana/ sightseeing/around-town/Kruja_2658v date $11.04 .2013, \mathrm{~h}$ 24.00

[3] Y. Drishti. National museum Gjergj Kastriot Skenderbeg, Kruja, page 137

[4] Google 2013: https://www.google.al/search?q=kruja+histor y\&source 12.04 .2013 h 23.30

[5] Institute of Culture Monuments " Gani Strazimiri”

[6] Rick Diamond. A lifestyle-based scenario for U.S. buildings: Implications for energy use.

[7] S. Leth-Petersen, M. Togeby. Demand for space heating in apartment blocks: measuring effect of policy measures aiming at reducing energy consumption, Energy Economics 23 (2001) 387-403.
[8] G. Branco, B. Lachal, P. Gallinelli, W. Weber. Predicted versus observed heat consumption of a low energy multifamily complex in Switzerland based on long-term experimental data, Energy and Building 36 (2004) 543-555.

[9] H. Jeeninga, M. Uyterlimde, J. Uitzinger. Energy Use of Energy Efficient Residences, Report ECN \& IVAM, 2001.

[10] United Nations Framework on Climate Ghange 2011

[11] L. Itard, F. Meijer. Towards a Sustainable Northern European Housing Stock: Figures, Facts and Future, IOS Press, 2008, ISBN: 978-1-58603-977-6.

[12] EuroACE, Towards Energy Efficient Buildings in Europe, final report June (ec.europa.eu), 2004.

[13] Parker and Cummings 2008, Vieira 2006

[14] European Commission 2008

[15] Sarah Darby and Rebecca White. Thermal comfort Environmental Change Institute, University of Oxford.

[16] Olivia Guerra, Laure Itard, Henk Visscher. The effect of occupancy and building characteristic on energy use for space and water heating in Dutch residential stock.

[17] R. Haas, H. Auer, P. Biermayr. The impact of consumer behavior on residential energy demand for space heating, Energy and Buildings 27 (1998) 195-205.

[18] A. L. Linde'n, A. Carlsson-Kanyama, B. Eriksson. Efficient and inefficient aspects of residential energy behavior: what are the policy instruments for change? Energy Policy 34 (2006) 1918-1927.

[19] M. W. Liddament, M. Orme. Energy and ventilation, Applied Thermal Engineering 18 (1998) 1101-1109.

[20] G. Iwashita, H. Akasaka. The effects of human behavior on natural ventilation rate and indoor air environment in summer - a field study on southern Japan, Energy \& Buildings 25 (1997) 195-205.

[21] 21. H.Erhorn. Influence of meteorological conditions on inhabitants' behavior in dwellings with mechanical ventilation, Energy and Buildings 11 (1988) 267-275. 